\title{
EFFECTS OF GROUND-WATER CHEMISTRY AND \\ FLOW ON QUALITY OF DRAINFLOW IN THE \\ WESTERN SAN JOAQUIN VALLEY, CALIFORNIA
}

By John L. Fio and David A. Leighton

U.S. GEOLOGICAL SURVEY

Open-File Report 94-72

Prepared in cooperation with the

PANOCHE WATER DISTRICT and the

CALIFORNIA DEPARTMENT OF WATER RESOURCES

$\frac{\infty}{\frac{1}{8}}$ 


\section{U.S. DEPARTMENT OF THE INTERIOR BRUCE BABBITT, Secretary}

\section{U.S. GEOLOGICAL SURVEY GORDON P. EATON, Director}

Any use of trade, product, or firm names in this publication is for descriptive purposes only and does not imply endorsement by the U.S. Government.

For sale by the U.S. Geological Survey

Earth Science Information Center

Open-File Reports Section

Box 25286, MS 517

Denver Federal Center

Denver, CO 80225

For additional information write to:

District Chief

U.S. Geological Survey

Federal Building, Room W-2233

2800 Cottage Way

Sacramento, CA 95825 


\title{
CONTENTS
}

\author{
Abstract 1 \\ Introduction 1 \\ Background 3 \\ Study area and geohydrologic setting $\mathbf{3}$ \\ Approach 6 \\ Sampling and analytical methods 6 \\ Water-level data 7 \\ Drainflow 7 \\ Ground-water flow model 7 \\ Flow paths and advective traveltimes 9 \\ Delineating contributing sources to drainflow 9 \\ Ground-water chemistry 10 \\ Conditions in $1954 \mathbf{1 0}$ \\ Conditions in 199013 \\ Ground-water flow 14 \\ Flow paths and advective traveltimes 14 \\ Contributing sources to drainflow $\mathbf{1 6}$ \\ Effects of ground water on quality of drainflow 21 \\ Summary and conclusions $\mathbf{2 6}$ \\ References cited 27
}

\section{FIGURES}

1,2. Maps showing:

1. Part of the western San Joaquin Valley and general area of study 2

2. Areal distribution of shallow observation wells, cluster sites, and geohydrologic sections in part of the western San Joaquin Valley 4

3. Geohydrologic sections showing average hydraulic heads and altitude of the water table projected onto the $A-A^{\prime}, B-B^{\prime}$, and $C-C^{\prime}$ geohydrologic sections 5

4. Map showing finite-difference grid and boundary conditions for the ground-water flow model 8

5. Stiff diagrams showing analysis of surface-water samples collected during low-flow conditions in 1954 from Little Panoche and Panoche Creeks 10

6,7. Geohydrologic sections showing:

6. General chemical quality of ground-water samples collected from observation wells at cluster sites projected onto geohydrologic sections $A-A^{\prime}, B-B^{\prime}$, and $C-C^{\prime} \mathbf{1 1}$

7. Selenium concentrations in water from observation wells at cluster sites projected onto geohydrologic sections $A-A^{\prime}, B-B^{\prime}$, and $C-C^{\prime} 12$

8. Graph showing isotopic composition of water from observation wells at cluster sites in part of the western San Joaquin Valley $\mathbf{1 6}$

9,10. Geohydrologic sections showing:

9. Simulated ground-water flow paths and advective traveltimes from the water table to sampling points at cluster sites projected onto geohydrologic sections $A-A^{\prime}, B-B^{\prime}$, and $C-C^{\prime} 17$

10. Tritium in water from observation wells at cluster sites projected onto geohydrologic sections $A-A^{\prime}, B-B^{\prime}$, and $C-C^{\prime} 18$ 
11-13. Maps showing:

11. Delineation of drained areas that intercept mostly recharge to the saturated zone, lateral ground-water flow, and upward-moving deep percolation in part of the western San Joaquin Valley 19

12. Recharge areas contributing to lateral ground-water flow and downslope drainflow in part of the western San Joaquin Valley 20

13. Installation dates of selected drainage systems in part of the western San Joaquin Valley 22

14. Graph showing drainwater flow and dissolved solids for drainage systems at sites 1,3 , and 4 from part of the western San Joaquin Valley 23

15,16. Maps showing:

15. Areal distribution of the seasonal variation in dissolved-solid concentrations in drainwater in part of the western San Joaquin Valley $\mathbf{2 4}$

16. Areal distribution of selenium concentrations in drainwater in part of the western San Joaquin Valley 25

17. Graph showing relation between measured selenium loads and drainwater flow for drainage systems at sites 1, 3, and 4 and total drainage in part of the western San Joaquin Valley 26

\section{TABLES}

1. Recharge to the saturated zone in the study area calculated as the sum of water applied and effective precipitation less consumptive use 9

2. Chemical, isotopic, and tritium analyses of ground-water samples collected at cluster sites, 199014 
Conversion Factors, Vertical Datum, and Water-Quality Information

\section{Conversion Factors}

\begin{tabular}{rcl}
\hline Multiply & By & To obtain \\
\hline centimeter $(\mathrm{cm})$ & 3.937 & inch \\
cubic meter per year $\left(\mathrm{m}^{3} / \mathrm{y}\right)$ & 35.31 & cubic foot per year \\
kilometer $(\mathrm{km})$ & 0.6214 & mile \\
meter $(\mathrm{m})$ & 3.281 & foot \\
meter per year $(\mathrm{m} / \mathrm{y})$ & 3.281 & foot per year \\
square kilometer $\left(\mathrm{km}^{2}\right)$ & 0.3861 & square mile \\
\hline
\end{tabular}

Temperature is given in degrees Celsius $\left({ }^{\circ} \mathrm{C}\right)$, which can be converted to degrees Fahrenheit $\left({ }^{\circ} \mathrm{F}\right)$ by the following equation:

$$
{ }^{\circ} \mathrm{F}=1.8\left({ }^{\circ} \mathrm{C}\right)+32 \text {. }
$$

\section{Vertical Datum}

Sea Level: In this report, "sea level" refers to the National Geodetic Vertical Datum of 1929--a geodetic datum derived from a general adjustment of the first-order level nets of the United States and Canada, formerly called Sea Level Datum of 1929.

\section{Water-Quality Information}

Trace-element concentrations in water samples are given in micrograms per liter $(\mu \mathrm{g} / \mathrm{L})$. One thousand micrograms per liter is equivalent to 1 milligram per liter $(\mathrm{mg} / \mathrm{L})$. Micrograms per liter is equivalent to "parts per billion."

\section{Abbreviations}

$\mu \mathrm{m}$, micrometer

meq/L, milliequivalents per liter

$\mu \mathrm{S} / \mathrm{cm}$, microsiemens per centimeter 


\title{
EFFECTS OF GROUND-WATER CHEMISTRY AND FLOW ON QUALITY OF DRAINFLOW IN THE WESTERN SAN JOAQUIN VALLEY, CALIFORNIA
}

\author{
By John L. Fio and David A. Leighton
}

\section{Abstract}

Chemical and geohydrologic data were used to assess the effects of regional ground-water flow on the quality of on-farm drainflows in a part of the western San Joaquin Valley, California. Shallow ground water beneath farm fields has been enriched in stable isotopes and salts by partial evaporation from the shallow water table and is being displaced by irrigation, drainage, and regional ground-water flow. Ground-water flow is primarily downward in the study area but can flow upward in some downslope areas. There are transitional areas between the downward and upward flow zones, where ground water can move substantial horizontal distances ( 0.3 to 3.6 kilometers) and can require 10 to 90 years to reach the downslope drainage systems. Simulation of ground-water flow to drainage systems indicates that regional ground water contributes to about 11 percent of annual drainflow.

Selenium concentrations in ground water and drainwater are affected by geologic source materials, partial evaporation from a shallow water table, drainage-system age, and regional groundwater flow. Temporal variability in drainflow quality is affected in part by the distribution of chemical constituents in ground water and the flow paths to the drainage systems. The mass flux of selenium in drainflows, or load, generally is proportional to flow, and reductions in drainflow quantity should reduce selenium loads over the short term. Uncertain changes in the distribution of ground-water quality make future changes in drainflow quality difficult to quantify.

\section{INTRODUCTION}

Salinity and drainage problems are common to irrigated agriculture in many arid regions of the world. As early as 1958, growers in the western San Joaquin Valley of California (fig. 1) began installing subsurface drainage systems to manage a shallow water table and soil salinity. Interest in the waterquality aspects of the resulting drainflow followed the discovery of high selenium concentrations in drainwater (Deverel and others, 1984; Presser and Barnes, 1984) and its detrimental effects on waterfowl populations at the Kesterson National Wildlife Refuge (Ohlendorf and others, 1986). Results from previous studies indicate that drainage systems can intercept a combination of irrigation water applied to the fields that overlay the drainage systems and regional ground-water flow paths that originate in areas upslope of the drainage systems (Fio and Deverel, 1991; Fio, 1994). Water-resources managers, attempting to reduce selenium loads from drainage systems, require information on the implications of regional groundwater flow paths for salt and selenium concentrations in drainwater.

This report describes results of a study of ground water and drainflow in the western San Joaquin Valley, California. The purpose of the study was to assess the effects of regional ground-water flow on salinity and selenium concentrations in on-farm drainflows. Chemical and stable isotope data from wellwater samples and simulated ground-water flow paths and advective traveltimes are used to describe processes affecting the current (1990) distribution of salinity and selenium in ground water. This information helps to explain the spatial and temporal variability in drainflow quality and implications for future changes as a result of changing water-use 


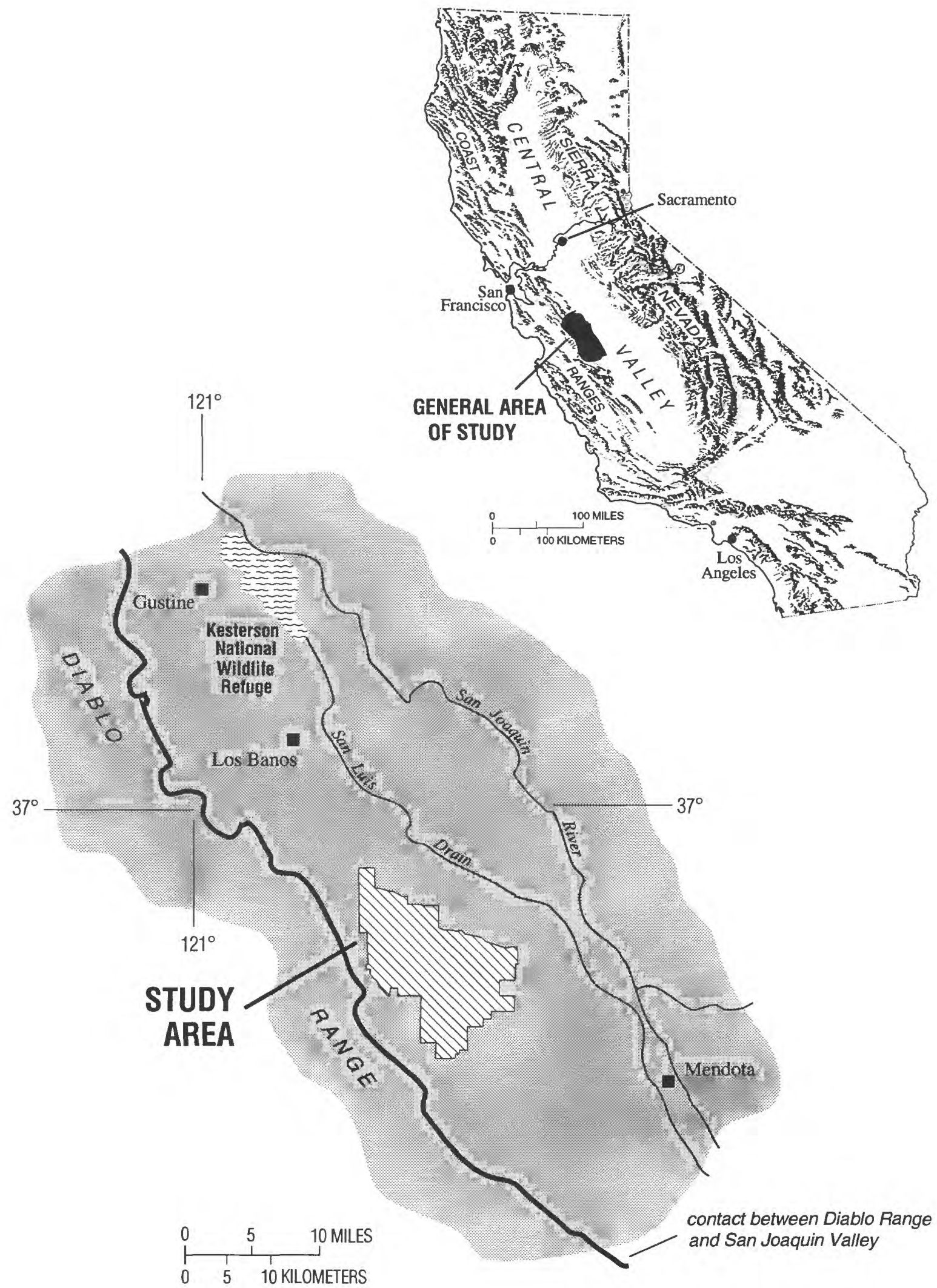

Figure 1. Part of the western San Joaquin Valley and general area of study. 
practices. This work was done in 1989-91 by the U.S. Geological Survey in cooperation with the Panoche Water District and the California Department of Water Resources.

\section{BACKGROUND}

Under predevelopment conditions, precipitation and seepage from streams draining the Coast Ranges provided recharge to the ground-water flow system in the western San Joaquin Valley; ground-water discharge was in low-lying areas adjacent to the river and along the valley floor as seepage into the San Joaquin River and evapotranspiration from a shallow water table (Mendenhall and others, 1916). The salts and minerals precipitated out by evaporating ground water accumulated over time in areas of ground-water discharge (Deverel and Gallanthine, 1989).

As intensive agricultural development in the valley began, the primary source of irrigation water was deep pumping of ground water. Historic demands for water resulted in drawdowns of the potentiometric surface as much as 30 to $60 \mathrm{~m}$ below predevelopment conditions (Belitz and Heimes, 1990), which minimized natural discharge and the area affected by a shallow water table. As more land was brought under production, greater leaching by land reclamation and irrigation practices mobilized soil salts in the unsaturated zone and displaced them downward in the soil profile to the underlying water table.

After 1958 and on completion of the Central Valley Project and California Aqueduct, the primary source of water for irrigation was surface water imported from northern California. The availability of abundant supplies of surface water resulted in a decrease in ground-water pumping and an increase in the total area irrigated, resulting in an increase of the potentiometric surface and area affected by a shallow water table (Belitz and Heimes, 1990). Evapotranspiration in areas where the water table was within about $2 \mathrm{~m}$ of land surface concentrated the soluble salts and selenium in ground water (Deverel and Fujii, 1988) and required the installation of drainage systems to prevent water logging in the crop root zone and further increase in soil salinity.

Currently (1990), the saturated thickness of the ground-water system is as much as $150 \mathrm{~m}$ and is characterized by a substantial downward component of flow (Belitz and Heimes, 1990). The downward flow is a response to historical pumping causing relatively large drawdowns, percolation of imported irrigation water, and continued deep pumping (Belitz and Heimes, 1990). Shallow ground water, with high salt and selenium concentrations, is being displaced downward and toward the drainage systems by irrigation water relatively low in salt and selenium concentrations (Deverel and Fujii, 1988). Salt concentrations in shallow ground water generally are highest in the low-lying areas that historically were areas of groundwater discharge and characterized by high soil salinity (Deverel and Gallanthine, 1989). Drainage systems intercept ground water from different depths below the water table, and therefore concentrations of salinity and selenium in the resulting drainwater depend in part on the depth distribution of chemical constituents and ground-water flow paths to the drain laterals (Fio and Deverel, 1991).

\section{STUDY AREA AND GEOHYDROLOGIC SETIING}

The study was done within the service area of the Panoche Water District in the central part of the western San Joaquin Valley. The boundaries of the study area, areal distribution of shallow observation wells (wells less than $6 \mathrm{~m}$ below land surface) and cluster sites (sites having one or more wells completed at different depths ranging from 3.8 to $29.3 \mathrm{~m}$ below land surface) in the study area, and three geohydrologic sections previously described by Fio (1994) are shown in figure 2. The northern part of Panoche Water District overlays the Little Panoche Creek alluvial fan, and the southern part of the district overlays the Panoche Creek alluvial fan. A part of the district in the west overlays the interfan area between the Little Panoche Creek and Panoche Creek alluvial fans.

Sediment texture, average hydraulic heads, and altitude of the water table are projected onto geohydrologic sections $A-A^{\prime}, B-B^{\prime}$, and $C-C^{\prime}$ in figure 3 . The upper $12 \mathrm{~m}$ of sediment are predominantly fine grained (more than 50 percent clay, silt, and sandy clay and silt) and overlay about $9 \mathrm{~m}$ of predominantly coarse-grained sediment (more than 50 percent sand, clayey and silty sand, gravel, and clayey, silty, and sandy gravel). The coarse-grained sediment is underlain by about $9 \mathrm{~m}$ of fine-grained sediment. At higher altitudes, the quantity of coarse-grained deposits are substantial, and the water table does not parallel land surface but slopes to the west, resulting in depths to water substantially greater than $3 \mathrm{~m}$ below land 


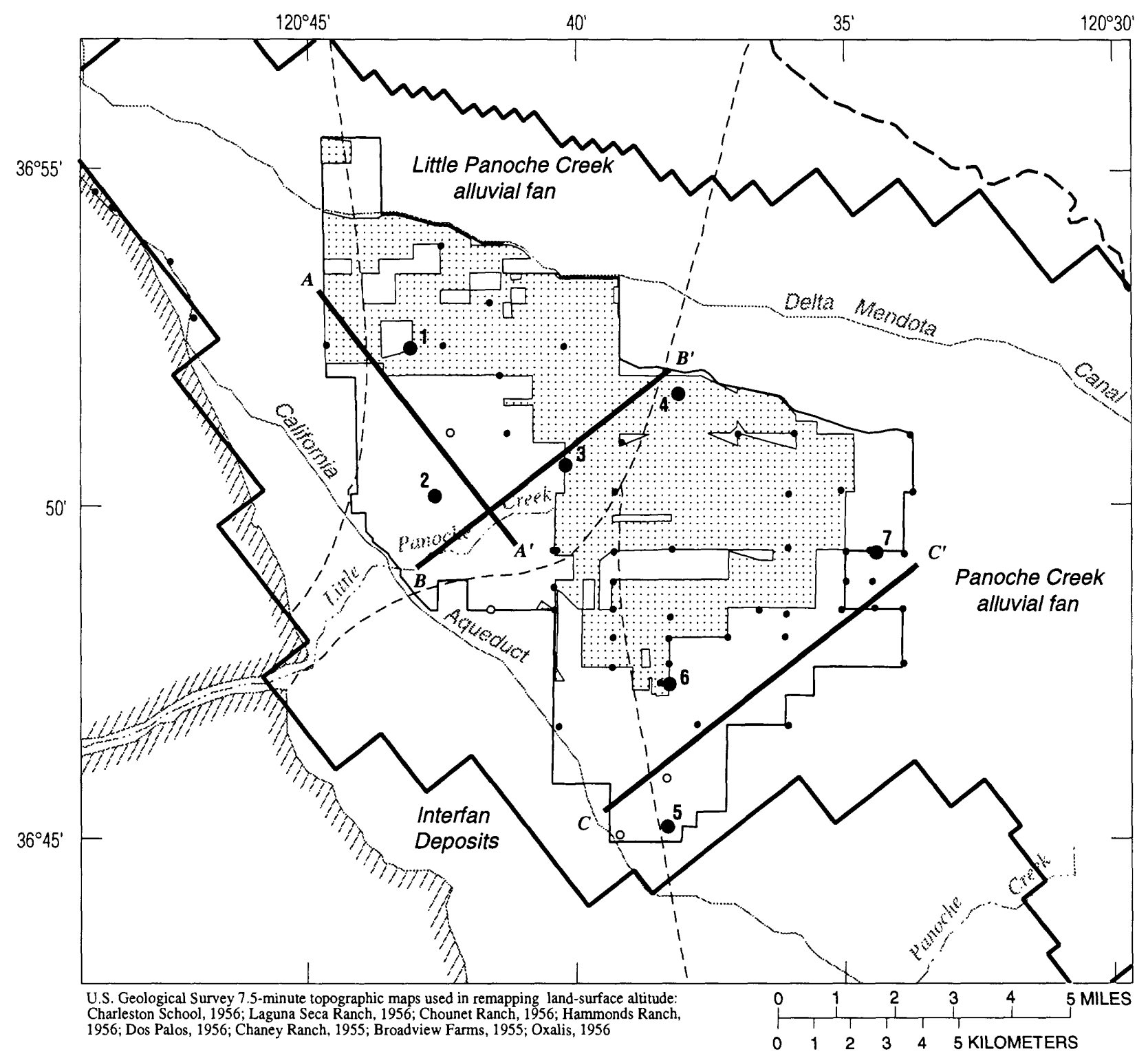

EXPLA N A T I O N

\begin{tabular}{|c|c|}
\hline$\because:$ & AREA UNDERLAIN BY DRAINAGE SYSTEMS \\
\hline & BOUNDARIES \\
\hline 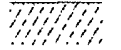 & Valley deposits \\
\hline & Ground-water flow model \\
\hline & Study area \\
\hline--- & Alluvial fan \\
\hline--- & Coast Ranges sediment \\
\hline$C^{\prime}$ & $\begin{array}{l}\text { LINE OF GEOHYDROLOGIC CROSS-SECTION } \\
\text { Shown in figures } 3,6,7,9 \text {, and } 10\end{array}$ \\
\hline
\end{tabular}

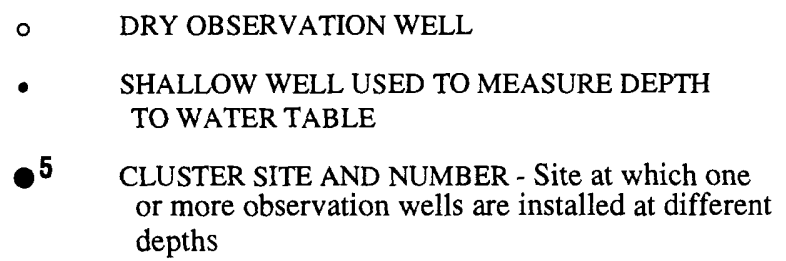

Figure 2. Areal distribution of shallow observation wells, cluster sites, and geohydrologic sections in part of the western San Joaquin Valley (blank areas in study area are undrained; drained areas outside the study area boundáries are not shown). 


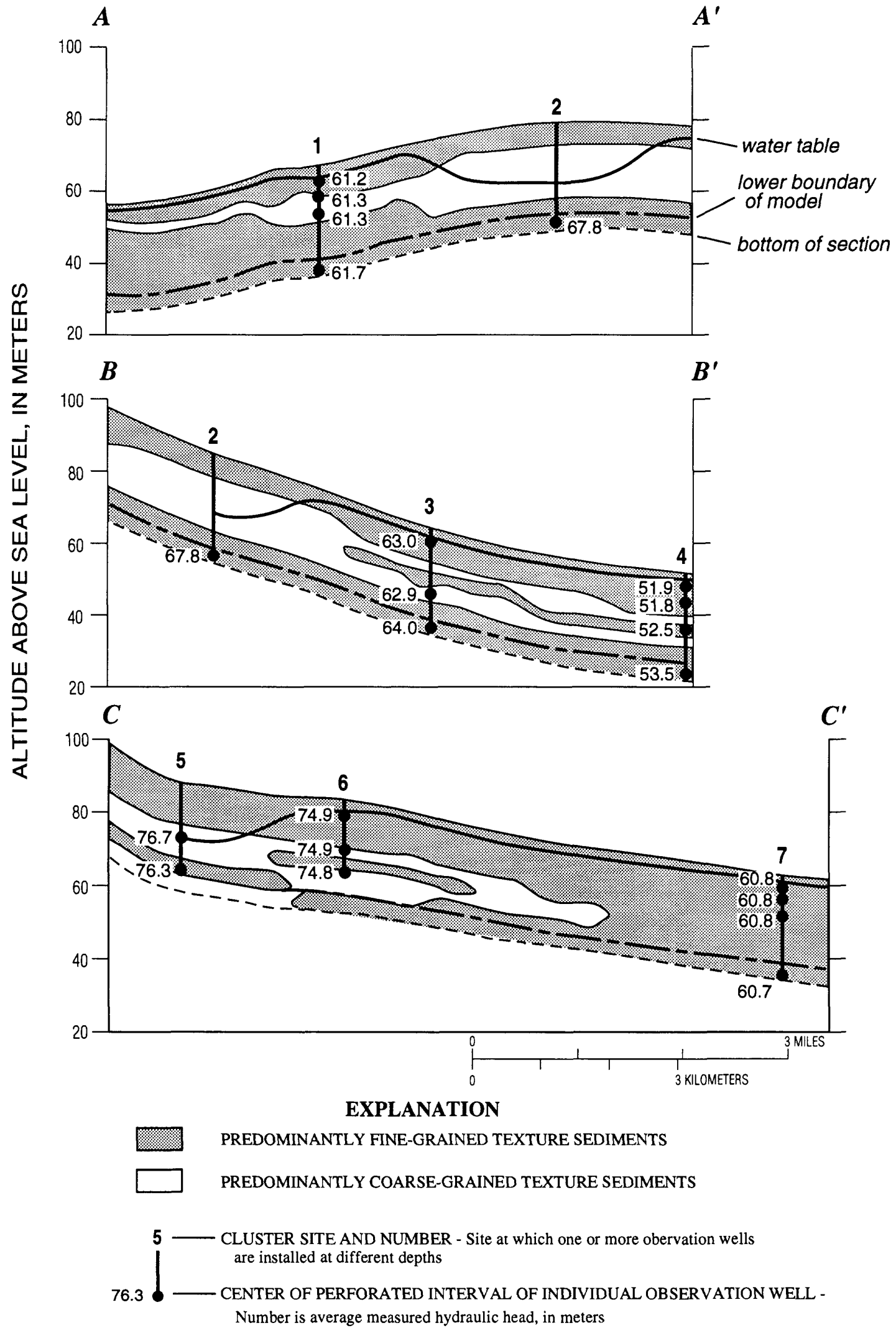

Figure 3. Average hydraulic heads and altitude of the water table projected onto the $A-A^{\prime}, B-B^{\prime}$, and $C-C^{\prime}$ geohydrologic sections. Locations of sections shown in figure 2. 
surface. In the low-lying areas, sediments are predominantly fine-grained and the water table is within $3 \mathrm{~m}$ of land surface; the water table in the low-lying areas gently slopes to the east paralleling the slope of the land surface. Hydraulic heads indicate that the vertical component of flow is variable; decreasing heads with depth in the upslope areas indicate downward flow, whereas increasing heads with depth in some downslope areas indicate upward flow.

Recharge to the ground-water flow system primarily is from irrigation water. Application of irrigation water typically consists of a preplant irrigation applied in the late winter or early spring, followed by periodic applications of water during the summer growing season. Recharge rates are greatest during preplant irrigation because greater quantities of water are applied in order to thoroughly wet the seed bed and because the absence of crop roots increases the quantity of water that reaches the saturated zone. In contrast, recharge to the saturated zone is negligible during the harvest and winter months when fields are nonirrigated and idle.

\section{APPROACH}

Chemical and hydrologic data were used with a ground-water flow model developed by Fio (1994) to assess the effects of ground-water flow paths and velocities for on-farm drainflow. Ground-water samples and water levels were collected in 1990-91 from observation wells, and monthly drainflow data were provided by Panoche Water District for 1986-88. Because the ground-water and drainflow sampling periods did not coincide, data were averaged and used with the flow model results to represent typical annual flow conditions for 1987-91.

\section{SAMPLING AND ANALYTICAL METHODS}

Ground-water samples were collected through Teflon tubing with positive displacement pumps placed down the wells. When well yields were too low or well-casing diameters too narrow for the positive displacement pumps, peristaltic pumps were used to collect the samples. Prior to sampling, the well was pumped until at least three well-casing volumes were removed. Ground water then was pumped through a flow-through chamber (Wood, 1981) where the electrical conductivity, temperature, $\mathrm{pH}$, and redox potential of the discharge were measured. The well was pumped until the measurements made with the flow-through chamber for consecutive well volumes did not vary more than 10 percent.
All sampling and filter apparatus were rinsed thoroughly with well water prior to sample collection. Bicarbonate and carbonate concentrations were determined in the field by incrementally titrating unfiltered samples with dilute sulfuric acid. Unfiltered samples for the analysis of stable isotopes and tritium were collected in glass bottles with polyethylene lids so that there was no air space. Samples to be analyzed for selenium were pressure filtered through filters having a nominal pore size of $0.45 \mu \mathrm{m}$ (micrometer) and collected in acid-washed bottles and preserved with hydrochloric acid to a $\mathrm{pH}$ of less than 2 . Samples for the determination of major ions and other trace elements were pressure filtered and acidified with nitric acid to a $\mathrm{pH}$ of less than 2. Samples collected for the determination of boron, chloride, sulfate, and silica were filtered but untreated.

The total concentration of all forms of selenium in water samples was determined by hydride generation and atomic absorption spectrometry (Cutter, 1978; Presser and Barnes, 1984). Major ions (calcium, magnesium, sodium, and potassium) and molybdenum were determined by atomic absorption spectrometry. Chloride was determined by colorimetry, boron by atomic emission, and sulfate by the turbidimetric procedure. These methods are described in detail by Fishman and Friedman (1989). The distribution of major ions in ground water was assessed using Stiff diagrams (Stiff, 1951) and geochemical modeling results from the computer program SNORM (Bodine and Jones, 1986). Stiff diagrams plot in an identical sequence the concentration [in milliequivalents per liter (meq/L)] of major cations to the left of zero and major anions to the right of zero. The width of the Stiff diagram is an approximate indication of the total ionic content of the water sample. The resulting points are connected to plot polygons that provide a visual assessment of the relative differences in ground-water chemistry. The computer program SNORM calculates the normative salt assemblage, or salt norm, of a water sample. The salt norm is an estimate of the equilibrium salt assemblage expected when a water sample is evaporated to dryness under land-surface conditions (Bodine and Jones, 1986).

The oxygen-18 isotopic composition of water samples was determined using the carbon dioxide equilibration method (Epstein and Mayeda, 1953) at the U.S. Geological Survey Isotope Fractionation Project Laboratory, Reston, Virginia. The results are reported relative to Vienna Standard Mean Ocean Water (V-SMOW) in the delta notation where 


$$
\delta^{18} \mathrm{O}=\frac{\left({ }^{18} \mathrm{O} /{ }^{16} \mathrm{O}\right)_{\text {sample }}-\left({ }^{18} \mathrm{O} /{ }^{16} \mathrm{O}\right)_{\mathrm{v} \text {-smow }}}{\left({ }^{18} \mathrm{O} /{ }^{16} \mathrm{O}\right)_{\mathrm{v}-\text { smow }}} \times 1,000 .
$$

Hydrogen-isotopic composition of water samples was determined by analyzing the hydrogen quantitatively extracted from the water (Kendall and Coplen, 1985). Hydrogen results are reported relative to V-SMOW in the permil notation. The standard deviations of the laboratory measurements of oxygen- and hydrogen-isotopic composition are 0.10 and 1 permil, respectively.

Tritium content in water samples was determined by the Environmental Isotope Laboratory at the University of Waterloo, Ontario, Canada, with scintillation counting after electrolytic enrichment (International Atomic Energy Agency, 1976). Tritium concentrations are expressed in tritium units (TU); $1 \mathrm{TU}$ is equal to 1 tritium atom in $10^{18}$ hydrogen atoms. All water samples with detectable quantities of tritium represent recharge that entered the study area after 1952 when large quantities of tritium were released into the environment through atmospheric nuclear weapons testing (Michel, 1989). Thus, ground-water samples with detectable quantities of tritium indicate an average traveltime of 38 years or less for recharge to move from the recharge point to the ground-water sampling point (1990). Samples that represent recharge entering the study area prior to 1952 have tritium concentrations that are less than $1 \mathrm{TU}$ and indicate average traveltimes greater than 38 years.

\section{WATER-LEVEL DATA}

Water-level measurements were collected biweekly from February 1990 through January 1991. The data from the observation wells were used to delineate the surface of the water table, whereas water levels from deeper wells at the cluster sites provided information on hydraulic heads for deeper parts of the aquifer. Hydraulic heads were calculated as the difference between land-surface altitude and measured water levels (Fio, 1994). As a consequence of land subsidence owing to aquifer compaction, the altitude of land surface was remapped as described in detail by Belitz and others (1992). Attitudinal differences between cluster sites were estimated from the distribution of remapped land-surface altitudes, and attitudinal differences between observation wells at each cluster site were measured in the field.

\section{DRAINFLOW}

Drainflow was measured from September 1986 through June 1988 by personnel from the Panoche Water District with a combination of flowmeters (21 drainage systems), electrical power-consumption records (13 drainage systems), and weir measurements (19 drainage systems). The weirs measured drainflow at selected points along the open channels that receive drainwater from all drainage systems in the study area. The drainflows were calculated by difference from the weir results and thus typically include drainflow from more than one unmetered drainage system. The flowmeter and power records represent continuous measurements compiled on a monthly basis, whereas the weir measurements are collected once a month and assumed to represent average monthly flow. Annual drain flow was estimated from measurements collected during February 1987 through January 1988. This data record was used because it represents the complete annual cycle between irrigated and nonirrigated conditions.

\section{GROUND-WATER FLOW MODEL}

A steady-state, finite-difference modeling approach was used by Fio (1994) to simulate average hydraulic heads and annual volumetric ground-water fluxes within and adjacent to the study area. A larger area was simulated so that conditions prescribed at the model boundaries would have minimal influence on results within the study area. The areal grid of model cells consists of 41 columns and 62 rows having dimensions of variable lengths and widths (fig. 4). The western and northern boundaries of the model are no flow, and the eastern and southern model boundaries are specified fluxes from a regional ground-water flow model (Belitz and others, 1992); fluxes were uniformly distributed at rates of $0.7 \mathrm{~m} / \mathrm{y}$ out of the model area across the eastern boundary and $0.08 \mathrm{~m} / \mathrm{y}$ into the model area across the southern boundary. The upper surface of the model corresponds to the water table, and vertically the model is divided into eight layers to provide detail on water-table conditions and ground-water flow to the drainage systems within an aquifer thickness of $25.6 \mathrm{~m}$. A free-surface boundary is used to simulate the water table, and groundwater flow to deeper parts of the aquifer (deep percolation) is simulated across the lower model boundary with general-head boundaries (McDonald and Harbaugh, 1988). 


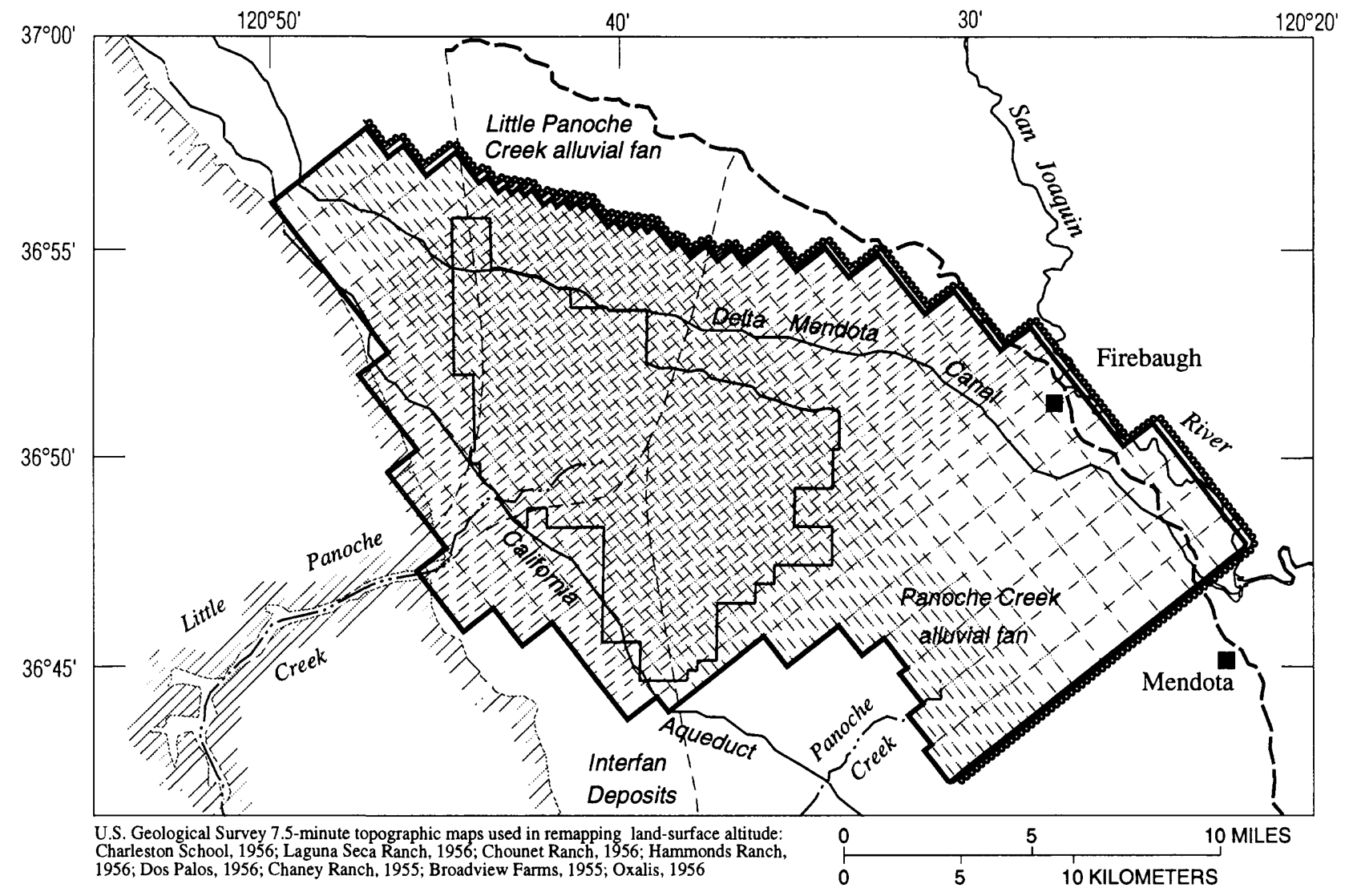

\section{EXPLANATION}

\begin{tabular}{|c|c|}
\hline & MODEL GRID - Dimensi \\
\hline & BOUNDARIES \\
\hline \multirow[t]{2}{*}{ ஜYYY } & Valley deposits \\
\hline & Study area \\
\hline \multirow[t]{3}{*}{----} & Alluvial fans \\
\hline & Coast Ranges sediment \\
\hline & MODEL BOUNDARIES \\
\hline & No flow \\
\hline 000 & Specified flow \\
\hline
\end{tabular}

Figure 4. Finite-difference grid and boundary conditions for the ground-water flow model (from Fio, 1994).

Source and sink terms represented in the model consist of recharge to the saturated zone, bare-soil evaporation, and drainflow (Fio, 1994). Recharge to the saturated zone was calculated from water delivery, effective precipitation, and consumptive-use data, and the results were areally specified in the model (table
1). Bare-soil evaporation and drainflow were simulated in the model as head-dependent sinks (McDonald and Harbaugh, 1988). The evaporation rate decreases linearly from $0.3 \mathrm{~m} / \mathrm{y}$ if the water table is less than $1.2 \mathrm{~m}$ below land surface to zero if the water table is greater than $2.1 \mathrm{~m}$ below land surface 
Table 1. Recharge to the saturated zone in the study area calculated as the sum of water applied and effective precipitation less consumptive use

[Average depth to water table in meters below land surface. $\mathrm{km}^{2}$, square kilometer]

\begin{tabular}{|c|c|c|c|c|c|}
\hline \multirow[b]{2}{*}{$\begin{array}{l}\text { Average depth } \\
\text { to water table }\end{array}$} & \multirow[b]{2}{*}{$\begin{array}{l}\text { Area } \\
\left(\mathrm{km}^{2}\right)\end{array}$} & \multicolumn{4}{|c|}{ Values in millions of cubic meters per year } \\
\hline & & $\begin{array}{c}\text { Water } \\
\text { applied } \\
(W a)\end{array}$ & $\begin{array}{c}\text { Effective } \\
\text { precipitation } \\
(P e)\end{array}$ & $\begin{array}{c}\text { Consumptive } \\
\text { use } \\
(C)\end{array}$ & $\begin{array}{l}\text { Recharge to the } \\
\text { saturated zone } \\
(R)\end{array}$ \\
\hline Greater than 3 meters . & 36.0 & 33.1 & 6.8 & 24.8 & 15.1 \\
\hline \multicolumn{6}{|c|}{ Less than or equal to 3 meters } \\
\hline Undrained $\ldots \ldots$ & 33.5 & 29.4 & 6.3 & 21.0 & 14.7 \\
\hline Drained & 91.9 & 74.5 & 17.5 & 66.2 & 25.8 \\
\hline Total & 161.4 & 137.0 & 30.6 & 112.0 & 55.6 \\
\hline
\end{tabular}

(Belitz and others, 1992). Drainflow was assumed to be proportional to the hydraulic-head gradient between ground water in the model cell and the effective altitude of the drain laterals (about $2.2 \mathrm{~m}$ below land surface) (Fio, 1994).

\section{FLOW PATHS AND ADVECTIVE TRAVELTIMES}

Ground-water flow paths and advective traveltimes were estimated from the specific discharge calculated for each model cell. For steady-state simulations, an analytical expression of the flow path in each cell was calculated by direct integration of the velocity components (Pollock, 1988). This method calculates the shape and direction of ground-water flow paths, and advective traveltimes can be estimated by integration of the linear velocity components along the flow path (Pollock, 1989).

The shape and direction of ground-water flow paths are tracked through the velocity vector field in either a backward or forward direction (Pollock, 1989). Flow paths, determined by backward tracking from the ground-water sampling points, show the simulated point of recharge for the ground-water sample; advective traveltimes along the path represent the average time of travel for water to move from the water table to the perforated interval of the observation well at the cluster site. A comparison between simulated traveltimes and traveltimes inferred from tritium data is used as a qualitative check on the flow model results. In contrast, tracking in a forward direction determines the discharge location of ground water along the flow path, assuming hydrologic conditions remain relatively constant.
Estimates of advective traveltimes are sensitive to the specified values of porosity because linear velocity is inversely proportional to porosity. Mean total porosities of coarse- and fine-grained sediments in the western San Joaquin Valley are about 0.41 and 0.42 , respectively (Belitz and others, 1992). Only a fraction of the total porosity is interconnected and contributes to the advective movement of water and solutes; hence, the drainable porosity, or instantaneous specific yield, was used to calculate linear velocities. The specific yield of sediments in the western San Joaquin Valley may range from 0.2 to 0.3 (Belitz and others, 1992), and a value of 0.2 was assumed reasonable for the drainable porosity of predominantly coarse-grained sediments. The drainable porosity of fine-grained sediment was assumed to be 0.1 on the basis of neutron-probe measurements following an irrigation period in one field with a predominantly clay loam soil (Fio and Deverel, 1991).

\section{DELINEATING CONTRIBUTING SOURCES TO DRAINFLOW}

A net flux averaged over the volume of the model cell is simulated with the ground-water flow model, and the dimensions of the model cells are such that most of the flow into a model cell simulating a drainage system is discharged as drainflow (Fio, 1994). Because the drainage systems are a major sink relative to the dimensions of the model cells in the study area, contributing sources to drainflows were estimated for subareas identified from backward tracking of a particle initially placed at a central location along the bottom face of each model cell in the drained area. If the ending location, or point of recharge, is in the same cell as the starting location, the net flux into the model cell originates mostly as recharge 
specified for the model cell. The maximum horizontal distance traveled along ground-water flow paths to the discharge points in this subarea is less than the width of a model cell $(402 \mathrm{~m})$. Similarly, if the point of recharge is located in model cells upslope from the starting locations, then the results delineate subareas that contribute recharge to downslope discharge. The horizontal distance traveled by this lateral-flowing ground water can be substantially greater than the width of a model cell. Finally, if the point of recharge is located at the lower boundary of the model, then the results identify subareas that discharge upwardmoving deep percolation. Simulated fluxes in the subareas identified by particle tracking were compiled and summed using the computer code ZONEBUDGET (Harbaugh, 1990). Quantitative analysis of model and particle-tracking results at the scale of individual model cells generally is unwarranted (Pollock, 1989); but when the results from several model cells are assessed in a combined fashion as described above, analysis will provide reasonable estimates on contributing sources of drainflow.

\section{GROUND-WATER CHEMISTRY}

Salts and minerals dissolved by percolating recharge are an important mechanism by which chemical constituents, such as selenium, are mobilized and transported in ground water in the western San Joaquin Valley (Presser and others, 1990). The chemical composition of ground water is further altered by mixing of different water types, enrichment of stable isotopes and soluble salts by partial evaporation, and removal of relatively insoluble salts and minerals by chemical precipitation (Deverel and Fujii, 1988; Deverel and Fio, 1991). Measured concentrations of chemical constituents and stable isotopes in the ground-water samples represent an integration of the processes that act on water moving between locations of recharge and discharge in the study area. Chemical data reported by Davis (1961) for shallow ground-water conditions in 1954 and ground-water samples collected for this study are compared in order to evaluate general changes in ground-water chemistry during the last 36 years.

\section{CONDITIONS IN 1954}

Chemical analyses of water samples collected in 1954 from Little Panoche and Panoche Creeks (Davis, 1961) were assessed with Stiff diagrams. The surfacewater samples reported by Davis (1961) were collected during low-flow conditions and represent shal-

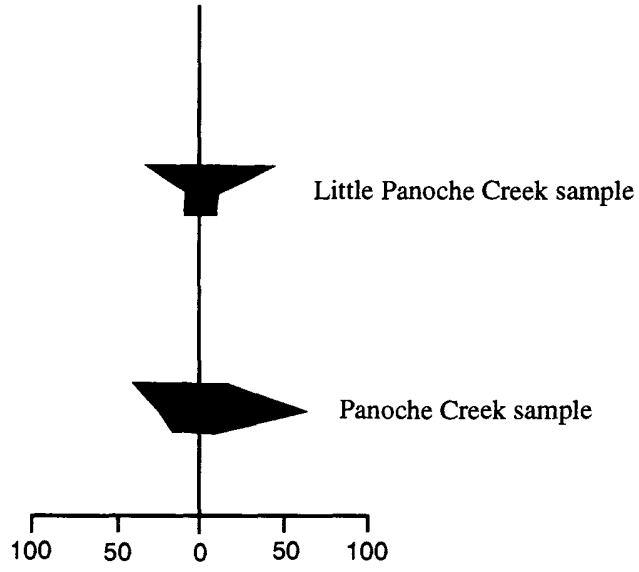

CONSTITUENT CONCENTRATION, IN MILLIEQUIVALENTS PER LITER

EXPLANATION OF STIFF DIAGRAM

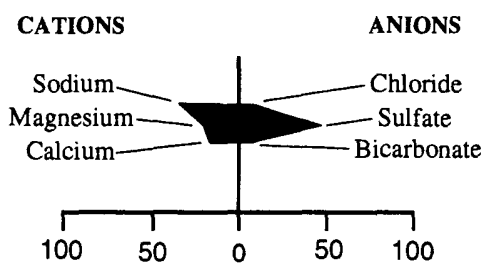

Figure 5. Analysis of surface-water samples collected during low-flow conditions in 1954 from Little Panoche and Panoche Creeks (Davis, 1961).

low ground-water chemistry prior to the importation of surface water to the valley in 1958. Ground water discharging into Little Panoche Creek in 1954 had a smaller total ionic content than ground water discharging into Panoche Creek (fig. 5). Dissolved-solid concentrations were $3,820 \mathrm{mg} / \mathrm{L}$ in the Little Panoche Creek sample and 5,250 $\mathrm{mg} / \mathrm{L}$ in the Panoche Creek sample (Davis, 1961). The Stiff diagrams have distinct shapes. The sample from Little Panoche Creek is dominated by sodium and chloride, whereas the sample from Panoche Creek is dominated by sodium and sulfate. Results from the computer program SNORM indicate that the water from Little Panoche Creek was dominated by dissolved halite ( 62 percent by weight), whereas dissolved bloedite represents a substantial proportion of the constituents in the water sample from Panoche Creek ( 50 percent by weight). Bloedite is capable of substituting sulfate with selenite, and its dissolution by percolating irrigation water has been hypothesized as a primary mechanism of 


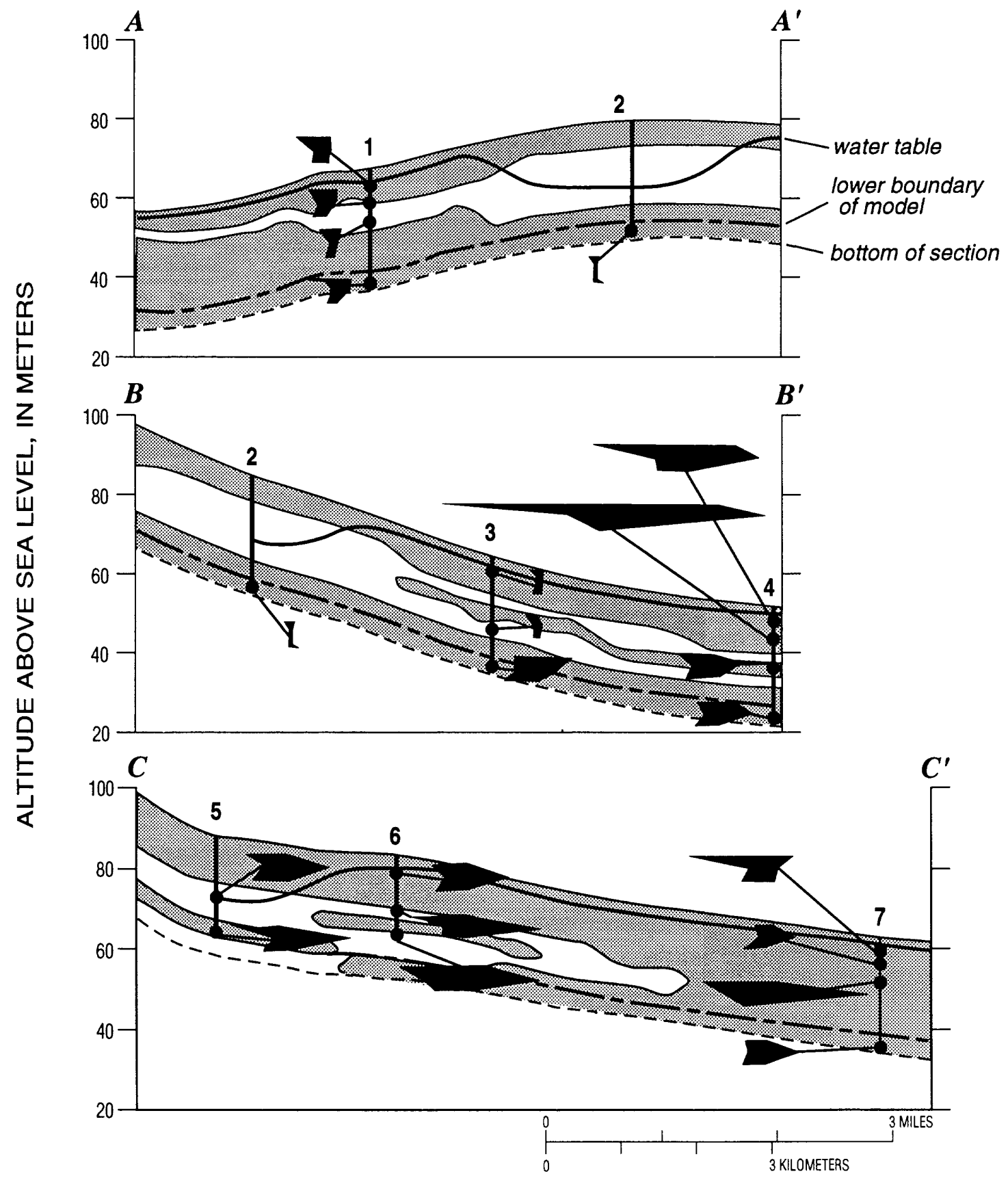

EXPLANATION OF STIFF DIAGRAM

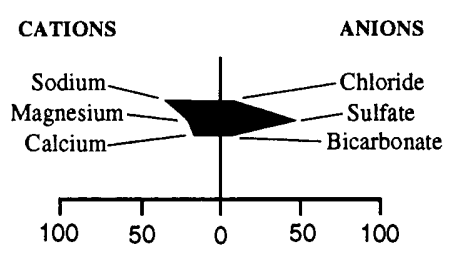

EXPLANATION

PREDOMINANTLY FINE-GRAINED TEXTURE SEDIMENTS

PREDOMINANTLY COARSE-GRAINED TEXTURE SEDIMENTS

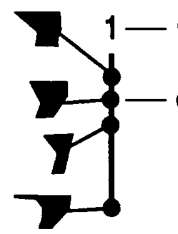

CLUSTER SITE AND NUMBER - Site at which one or more obervation wells are completed at different depths

CENTER OF PERFORATED INTERVAL OF INDIVIDUAL OBSERVATION WELL -

Polygon is Stiff diagram showing constituențs in milliequivalents per liter. Differences in configuration reflect differences in chemical character. The area of the diagram is an indication of dissolved-solids concentration. The larger the diagram, the higher the dissolved-solids concentration (Stiff, 1951)

Figure 6. General chemical quality of ground-water samples collected from observation wells at cluster sites projected onto geohydrologic sections $A-A^{\prime}, B-B^{\prime}$, and $C-C^{\prime}$. Locations of sections shown in figure 2. 


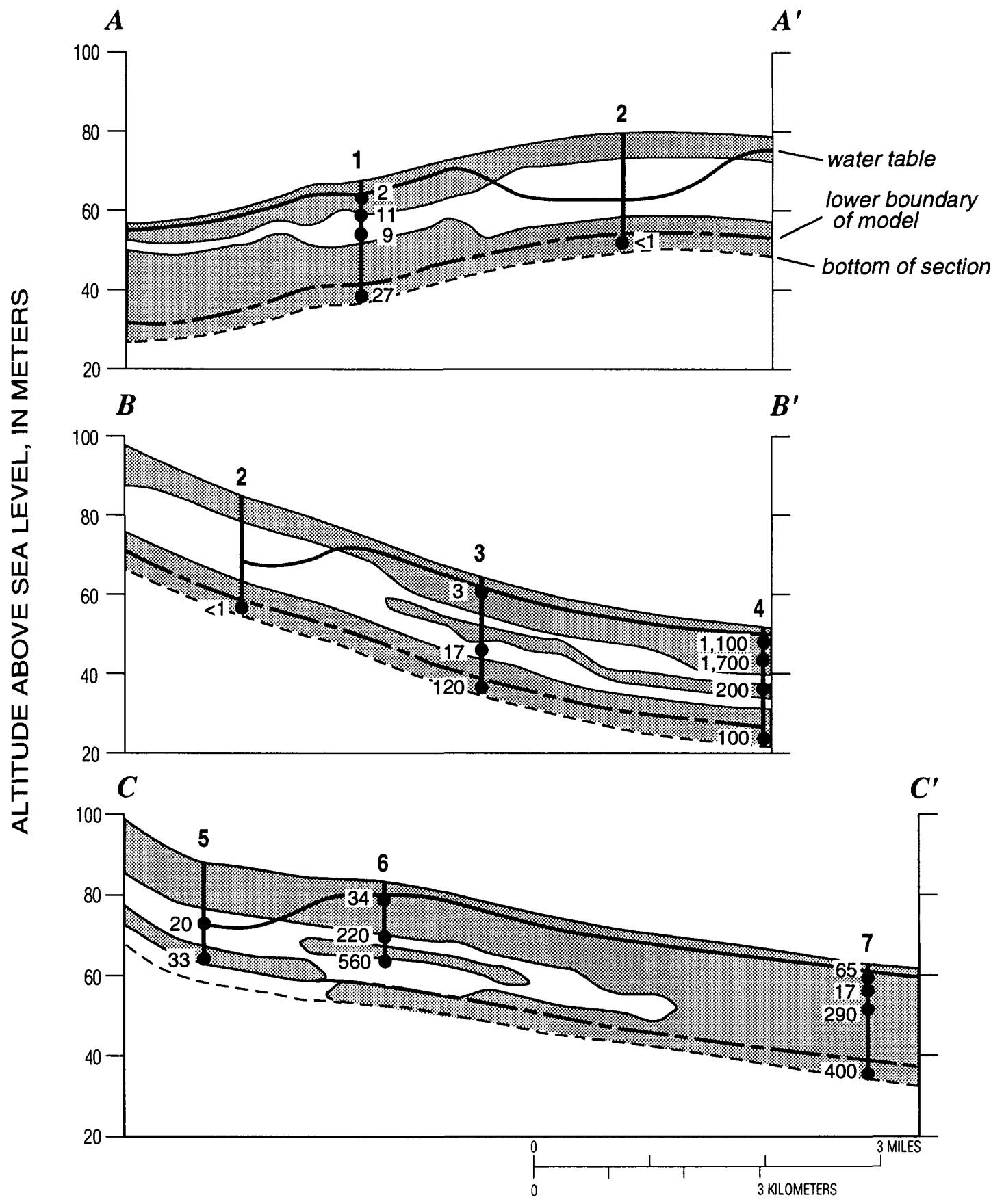

EXPLANATION

PREDOMINANTLY FINE-GRAINED TEXTURE SEDIMENTS

PREDOMINANTLY COARSE-GRAINED TEXTURE SEDIMENTS

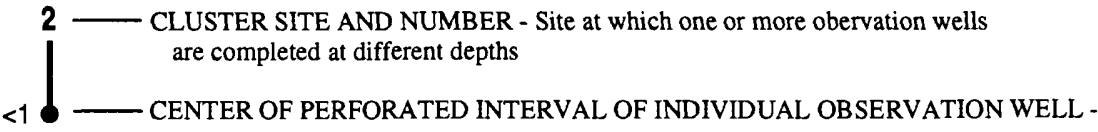

Number is selenium concentration, in micrograms per liter. <, actual value is less than value shown

Figure 7. Selenium concentrations in water from observation wells at cluster sites projected onto geohydrologic sections $A-A^{\prime}, B-B^{\prime}$, and $C-C^{\prime}$. Locations of sections shown in figure 2 . 
selenium mobilization in the western San Joaquin Valley (Presser and others, 1990; Deverel and Fio, 1991).

Chemical differences between the Little Panoche and Panoche Creek water samples are related to differences in the types of rocks in their respective drainage basins. Davis (1961) reported that the drainage basin of Little Panoche Creek consists of exposed rocks of the Franciscan Complex of Tertiary age (41 percent), marine sedimentary rocks of Cretaceous age (25 percent), and continental deposits of Tertiary age (34 percent). Surficial exposures of marine sedimentary rocks of Tertiary age are absent from the drainage basin of Little Panoche Creek. The sodium chloride water associated with Little Panoche Creek is attributed to the Panoche Formation of Cretaceous age (Presser and others, 1990), which consists of a substantial area of the exposed Cretaceous rocks (Dibblee, 1975). In contrast, Davis (1961) reported that the area drained by Panoche Creek consists of the Franciscan Complex (17 percent), marine sedimentary rocks of Cretaceous age (26 percent), continental deposits of Tertiary age (15 percent), and marine sedimentary rocks of Tertiary age (42 percent). The seleniferous sulfate water associated with Panoche Creek is attributed to the Moreno (Cretaceous age) and Kreyenhagen (Tertiary age) Formations (Presser and others, 1990). Selenium concentrations in water samples from Little Panoche Creek are less than $2 \mu \mathrm{g} / \mathrm{L}$, whereas samples from Panoche Creek range from 5 to $57 \mu \mathrm{g} / \mathrm{L}$ (Presser and others, 1990).

\section{CONDITIONS IN 1990}

Chemical data for the 1990 ground-water samples are shown in table 2. Cation and anion data were used to plot Stiff diagrams for ground water at the cluster sites (fig. 6); selenium concentrations at the cluster sites are shown in figure 7 . The results provide a visual means of grouping the samples on the basis of Stiff diagram shape, selenium concentration, and location in the study area. Ground water at cluster sites 1 and 2 and the two shallowest samples from site 3 (4.9 and $17.2 \mathrm{~m}$ below land surface) is low in total ionic content and selenium (less than 1 to 27 $\mu \mathrm{g} / \mathrm{L})$. Results from the computer program SNORM indicate that halite represents an average of 38 percent (by weight) of the chemical constituents in these samples. The Stiff diagrams resemble that of waters from Little Panoche Creek (fig. 5) presumably because the water originated as recharge to sediments on the Little Panoche Creek alluvial fan. In contrast, the
Stiff diagrams for ground-water samples from site 4 (17.2 and $29.3 \mathrm{~m}$ below land surface), site 5 (17.4 and $26.5 \mathrm{~m}$ below land surface), site 6 (3.8 m below land surface), and site 7 (6.8 and $29.3 \mathrm{~m}$ below land surface) resemble waters from Panoche Creek (fig. 5) and thus represent ground water originating as recharge on the Panoche Creek alluvial fan. This second group of samples has greater proportions of sulfate and a greater total ionic content than the first group of samples. Selenium concentrations range from 20 to $400 \mu \mathrm{g} / \mathrm{L}$, and bloedite represents an average of 33 percent (by weight) of the chemical constituents.

The remaining water samples $(27.8 \mathrm{~m}$ below land surface from site $3,4.0$ and $8.3 \mathrm{~m}$ below land surface from site 4, 13.0 and $19.4 \mathrm{~m}$ below land surface from site 6 , and 5.2 and $11.4 \mathrm{~m}$ below land surface from site 7) are characterized as having a large total ionic content and variable Stiff diagram shapes. The Stiff diagrams for the water samples in this third group do not resemble either of the two water types in figure 5 and probably represent ground water that has been altered by physical or chemical processes, or both. With the exception of a sample from site $7(5.2 \mathrm{~m}$ below land surface), selenium concentrations in this group range from 120 to $1,700 \mu \mathrm{g} / \mathrm{L}$.

Stable hydrogen- and oxygen-isotopes provide insight into the processes that altered the concentration of chemical constituents in the third group of water samples. The deuterium and oxygen-18 composition of samples from all the sites, expressed in the delta notation, are plotted in figure 8 with lines showing the average isotopic composition of global meteoric water (Craig, 1961) and the average isotopic composition of shallow ground water in the western San Joaquin Valley (Davis and Coplen, 1989). Most of the samples from the third group deviate from the global meteoric water line and average line for western San Joaquin Valley ground water. Regression analyses of the data points estimate an intercept of -24.9 and a slope of 4.83 , with a correlation coefficient $\left(r^{2}\right)$ of 0.96 . The slope of 4.83 is similar to the value of 4.28 (Deverel and Fujii, 1988) and 4.09 (Deverel and Fio, 1991) determined for shallow ground-water samples in drained areas in and near the study area, indicating enrichment by partial evaporation. This ground water probably was at or near land surface in the past, and partial evaporation from the shallow water table resulted in enrichment of stable isotopes and increased concentrations of salinity and selenium (Deverel and Fujii, 1988). The increase in ionic strength and exceedance of the solubility 
Table 2. Chemical, isotopic, and tritium analyses of ground-water samples collected at cluster sites, 1990

[Site identification number: Unique number for each site based on the latitude and longitude of the site. First six digits are perforated interval is in meters below land surface. $\mu \mathrm{S} / \mathrm{cm}$, microsiemens per centimeter; $\mathrm{mg} / \mathrm{L}$, milligram per liter; $\mu \mathrm{g} / \mathrm{L}$,

\begin{tabular}{|c|c|c|c|c|c|c|c|c|}
\hline $\begin{array}{l}\text { Cluster } \\
\text { site } \\
\text { (fig. 2) }\end{array}$ & $\begin{array}{c}\text { Site } \\
\text { identification } \\
\text { number }\end{array}$ & $\begin{array}{l}\text { Depth to } \\
\text { center of } \\
\text { perforated } \\
\text { interval }\end{array}$ & $\begin{array}{c}\text { Specific } \\
\text { conduct- } \\
\text { ance } \\
(\mu \mathrm{S} / \mathrm{cm})\end{array}$ & $\begin{array}{l}\mathrm{pH} \\
\text { (stand- } \\
\text { (ard } \\
\text { units) }\end{array}$ & $\begin{array}{l}\text { Calcium, } \\
\text { dis- } \\
\text { solved } \\
(\mathrm{mg} / \mathrm{L})\end{array}$ & $\begin{array}{l}\text { Magne- } \\
\text { sium, } \\
\text { dis- } \\
\text { solved } \\
(\mathrm{mg} / \mathrm{L})\end{array}$ & $\begin{array}{c}\text { Sodium, } \\
\text { dis- } \\
\text { solved } \\
(\mathrm{mg} / \mathrm{L})\end{array}$ & $\begin{array}{l}\text { Potas- } \\
\text { sium, } \\
\text { dis- } \\
\text { solved } \\
(\mathrm{mg} / \mathrm{L})\end{array}$ \\
\hline \multirow[t]{4}{*}{1} & 365221120430904 & 5.0 & -- & 7.1 & 150 & 35 & 570 & 2.9 \\
\hline & 365221120430903 & 8.4 & 3,190 & 7.3 & 220 & 49 & 410 & 3.2 \\
\hline & 365221120430902 & 13.5 & 2,630 & 7.4 & 170 & 30 & 340 & 1.5 \\
\hline & 365221120430901 & 29.3 & 3,240 & 7.4 & 240 & 66 & 390 & 1.9 \\
\hline 2 & 365008120423901 & 28.4 & 1,190 & 8.0 & 39 & 12 & 190 & 1.4 \\
\hline \multirow[t]{3}{*}{3} & 365036120401603 & 4.9 & 2,190 & 7.2 & 150 & 27 & 300 & 1.9 \\
\hline & 365036120401602 & 17.2 & 2,150 & 7.4 & 100 & 24 & 300 & 1.4 \\
\hline & 365036120401601 & 27.8 & 6,720 & 7.2 & 620 & 270 & 520 & 4.5 \\
\hline \multirow[t]{4}{*}{4} & 365140120380604 & 4.0 & 13,200 & 7.7 & 530 & 360 & 2,400 & 3.0 \\
\hline & 365140120380603 & 8.3 & 23,300 & 7.6 & 430 & 710 & 5,000 & 3.3 \\
\hline & 365140120380602 & 17.2 & 5,690 & 7.6 & 490 & 190 & 720 & 2.1 \\
\hline & 365140120380601 & 29.3 & 4,330 & 7.6 & 510 & 120 & 480 & 2.5 \\
\hline \multirow[t]{2}{*}{5} & 364511120381902 & 17.4 & 5,710 & 7.2 & 500 & 180 & 800 & 2.7 \\
\hline & 364511120381901 & 26.5 & 7,320 & 7.3 & 460 & 200 & 1,300 & 4.9 \\
\hline \multirow[t]{3}{*}{6} & 364719120381702 & 3.8 & 6,370 & 7.4 & 540 & 220 & 840 & 8.5 \\
\hline & 364719120381701 & 13.0 & 9,010 & 7.4 & 440 & 310 & 1,600 & 4.0 \\
\hline & 364719120381703 & 19.4 & 9,990 & 7.4 & 480 & 490 & 1,700 & 5.1 \\
\hline \multirow[t]{4}{*}{7} & 364919120343204 & 5.2 & 10,900 & 7.5 & 540 & 190 & 2,100 & 7.6 \\
\hline & 364919120343203 & 6.8 & 3,500 & 7.5 & 450 & 110 & 330 & 2.3 \\
\hline & 364919120343202 & 11.4 & 10,600 & 7.5 & 410 & 560 & 1,700 & 3.5 \\
\hline & 364919120343201 & 29.3 & 5,010 & 7.5 & 460 & 240 & 520 & 2.9 \\
\hline
\end{tabular}

products of slightly soluble minerals altered the chemical composition and shape of the Stiff diagrams. The spatial distribution of these enriched waters reflect displacement and mixing, and evaluation of their contribution to drainflow quality require quantification of ground-water flow paths and advective traveltimes to the on-farm drainage systems.

\section{GROUND-WATER FLOW}

\section{FLOW PATHS AND ADVECTIVE TRAVELTIMES}

Ground-water flow paths simulated by the flow model are shown in figure 9. Flow is downward at the higher altitudes near sites 2 and 5 and at the fan margins near sites 1,6 , and 7 . In contrast, flow is upward in downslope areas of the $B-B^{\prime}$ section. The upward flow paths at site 4 represent recharge that enters the system upslope of site 4 and moves along deep flow paths to locations beneath site 4 . There are transitional areas between the downward and upward flow (site 3), and ground water moves horizontally for substantial distances prior to interception by the drainage systems. Advective traveltimes from the water table to the sampling points at the cluster sites range from 1 to 49 years (advective traveltimes from the sampling points to the discharge locations are not reported in figure 9).

Tritium analyses of ground-water samples were used to qualitatively assess flow paths and traveltimes simulated by the flow model. Tritium was detected 
latitude, next seven digits are longitude, and final two digits are a sequence number to uniquely identify each site. Depth of microgram per liter; TU, tritium unit; <, actual value is less than value shown; --, no data]

\begin{tabular}{|c|c|c|c|c|c|c|c|c|c|}
\hline $\begin{array}{c}\text { Bicar- } \\
\text { bonate, } \\
(\mathrm{mg} / \mathrm{L} \\
\left.\text { as } \mathrm{HCO}_{3}\right)\end{array}$ & $\begin{array}{l}\text { Sulfate, } \\
\text { dis- } \\
\text { solved } \\
(\mathrm{mg} / \mathrm{L})\end{array}$ & $\begin{array}{l}\text { Chlo- } \\
\text { ride, } \\
\text { dis- } \\
\text { solved } \\
(\mathrm{mg} / \mathrm{L})\end{array}$ & $\begin{array}{c}\text { Nitrogen, } \\
\text { nitrite plus } \\
\text { nitrate, } \\
\text { dissolved } \\
\text { (mg/L as } \mathrm{N} \text { ) }\end{array}$ & $\begin{array}{c}\text { Boron, } \\
\text { dis- } \\
\text { solved } \\
(\mu \mathrm{g} / \mathrm{L})\end{array}$ & $\begin{array}{c}\text { Molyb- } \\
\text { denum, } \\
\text { dis- } \\
\text { solved } \\
(\mu \mathrm{g} / \mathrm{L})\end{array}$ & $\begin{array}{l}\text { Sele- } \\
\text { nium, } \\
\text { dis- } \\
\text { solved } \\
(\mu \mathrm{g} / \mathrm{L})\end{array}$ & $\begin{array}{c}\text { Delta } \\
\text { deuterium } \\
\text { (per- } \\
\text { mil) }\end{array}$ & $\begin{array}{c}\text { Delta } \\
\text { oxygen-18 } \\
\text { (per- } \\
\text { mil) }\end{array}$ & $\begin{array}{c}\text { Tritium } \\
\text { (TU) }\end{array}$ \\
\hline 476 & 660 & 470 & 6.9 & 8,400 & 4 & 2 & -67.5 & -8.95 & 12 \\
\hline 308 & 630 & 520 & 19 & 7,900 & 2 & 11 & -66.5 & -8.70 & 15 \\
\hline 220 & 390 & 380 & 16 & 7,300 & 2 & 9 & -66.5 & -8.65 & 15 \\
\hline 135 & 720 & 570 & 26 & 6,600 & 1 & 27 & -60.4 & -7.85 & 8 \\
\hline 177 & 180 & 180 & 6.4 & 5,700 & 6 & $<1$ & -65.5 & -8.35 & 18 \\
\hline 328 & 400 & 300 & 17 & 3,900 & 1 & 3 & -70.5 & -9.50 & 29 \\
\hline 207 & 410 & 230 & 23 & 7,500 & 18 & 17 & -69.5 & -9.05 & 36 \\
\hline 134 & 1,500 & 1,500 & 79 & 5,400 & 12 & 120 & -60.5 & -7.10 & 6 \\
\hline 170 & 4,400 & 2,200 & 89 & 36,000 & 120 & 1,100 & -58.0 & -6.65 & 13 \\
\hline 195 & 8,400 & 4,000 & 160 & 23,000 & 330 & 1,700 & -47.5 & -4.85 & 5 \\
\hline 129 & 2,600 & 450 & 16 & 7,400 & 32 & 200 & -56.5 & -6.85 & $<1$ \\
\hline 107 & 2,000 & 320 & 14 & 3,900 & 60 & 100 & -60.5 & -7.75 & $<1$ \\
\hline 373 & 2,800 & 170 & 14 & 9,900 & 8 & 20 & -69.0 & -9.15 & 18 \\
\hline 351 & 4,000 & 210 & 12 & 14,000 & 12 & 33 & -68.5 & -8.90 & 27 \\
\hline 626 & 2,900 & 470 & 24.4 & 6,500 & 30 & 34 & -69.5 & -9.05 & 16 \\
\hline 421 & 4,700 & 560 & 25.8 & 17,000 & 18 & 220 & -58.5 & -6.50 & $<1$ \\
\hline 194 & 4,900 & 800 & 190 & 12,000 & 10 & 560 & -57.0 & -6.25 & $<1$ \\
\hline 761 & 800 & 1,100 & 230 & 19,000 & 8 & 65 & -58.0 & -7.15 & 19 \\
\hline 160 & 1,800 & 140 & 6.9 & 2,500 & 21 & 17 & -69.5 & -9.40 & 15 \\
\hline 282 & 5,900 & 290 & 38.9 & 22,000 & 40 & 290 & -69.0 & -8.80 & 16 \\
\hline 127 & 2,300 & 290 & 37.8 & 5,800 & 52 & 400 & -59.5 & -7.15 & 2 \\
\hline
\end{tabular}

in most of the water samples (fig. 10), indicating that most ground water within $30 \mathrm{~m}$ of land surface is recharge that entered the study area after 1952 (within 38 years of the sampling date). Water particles in most simulated flow paths have traveltimes less than 38 years (fig. 9) and agree with the tritium data. The exceptions are the samples from the two pairs of deepest wells at sites 4 and 6 , which lack detectable quantities of tritium indicating that this water entered the system prior to 1952; the flow model indicates that ground water at these sampling points entered the system after 1952. The discrepancy between simulated traveltimes and tritium data at sites 4 and 6 indicates a need for further evaluation of the data and model results at these sites.
At site 4 , most of the ground water at depths of 4.0 and $8.3 \mathrm{~m}$ below land surface consists of post-1952 recharge, whereas ground water at greater depths (17.2 and $29.3 \mathrm{~m}$ below land surface) consists mostly of recharge entering the aquifer before 1952 . The sample collected from $17.2 \mathrm{~m}$ below land surface is isotopically enriched (fig. 8), indicating it was displaced downward from a location near land surface in the past and is now moving upward toward the water table at site 4 . In contrast, the sample from $29.3 \mathrm{~m}$ below land surface is nonenriched, indicating it probably originated farther upslope at a location with a deeper water table. The water at the $29.3 \mathrm{~m}$ depth also is moving upward toward the water table at site 4 . The isotopic composition of the two sam- 


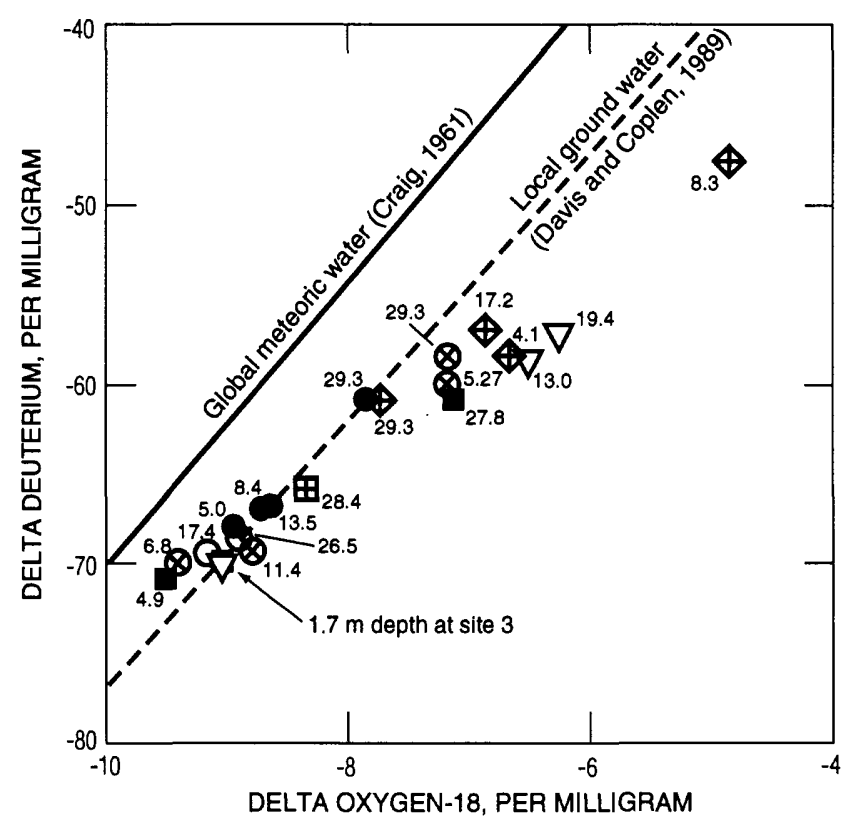

EXPLANATION

CLUSTER SITE - Site at which one or more observation wells are completed at different depths. Number indicates sample depth, in meters below land surface

$\begin{array}{rr}29.3 & \text { Site 1 } \\ \text { 田 } & \text { Site 2 } \\ \square & \text { Site 3 } \\ \boldsymbol{\square} & \text { Site 4 } \\ \mathbf{0} & \text { Site 5 } \\ \boldsymbol{\nabla} & \text { Site 6 } \\ \mathbf{8} & \text { Site 7 }\end{array}$

Figure 8. Isotopic composition of water from observation wells at cluster sites in part of the western San Joaquin Valley.

ples indicates ground water at these depths originated at different locations upslope of site 4 . Traveltimes simulated by the flow model do not include the time necessary for ground water to move from the upslope locations. Thus, the model and tritium results are consistent with respect to the limitations of the model boundaries in the vertical direction.

At site 6, ground water at 13.0 and $19.4 \mathrm{~m}$ below land surface consists of mostly recharge that entered the system prior to 1952 and is isotopically enriched, indicating partial evaporation from a shallow water table (fig. 8). Tritium data indicate that recharge entering the system after 1952 required more than 38 years to move from the water table near land surface to the 13.0 and $19.4 \mathrm{~m}$ depths, but model simulation indicates that traveltimes were less than 38 years (12 and 16 years, respectively). The drainage system at site 6 was installed in 1985 ( 5 years prior to the sampling date), and hydrologic conditions prior to 1985 would have been different because drainage systems were not yet installed. Sufficient time probably has not elapsed for the post-1952 recharge to reach the deeper depths under the recharge and drainage conditions simulated by the model. Thus, the model results are limited because steady-state conditions are simulated in areas undergoing recent hydrologic changes.

The results from the isotope and tritium data indicate that the movement and fate of chemical constituents in the aquifer are altered by changing hydrologic conditions. For example, isotopically enriched ground water is upwardly displaced at site 4 by nonenriched ground water originating upslope of the site. The combination of upward flow, irrigation, and drainage has resulted in a distinct depth distribution of ground-water quality; the greatest concentration of salinity and selenium at site 4 is $8.4 \mathrm{~m}$ below land surface (figs. 6 and 7). The distribution of drainflow sources relative to the horizontal and vertical distribution of ground-water flow paths must therefore be assessed to understand the relation between regional ground-water flow and drainflow quality.

\section{CONTRIBUTING SOURCES TO DRAINFLOW}

Contributing sources to drainflow are delineated from results of flow model simulation by identification of drainage systems that discharge solely irrigation recharge and ground water within the field above the drainage system, substantial quantities of lateral-flowing ground water, and upward-moving deep percolation (fig. 11). Although most of the drainflow originates as recharge in the drained area, regional ground-water flow along lateral flow paths and upward-moving deep percolation contributes about 11 percent of the total drainflow (Fio, 1994). Figure 12 shows the recharge areas that contribute lateral-flowing ground water to downslope drainflow. Most of the recharge areas are in undrained areas upslope of the drainage systems, and the horizontal displacement of flow paths ranges from 0.3 to $3.6 \mathrm{~km}$ and requires from 10 to 90 years to reach the downslope drainage systems. The upward-moving deep percolation probably originates in areas west of the recharge areas in figure 12 and presumably moves along flow paths that extend into deeper parts of the aquifer beneath the lower model layer and discharge as upward flow in the downslope areas. Upwardmoving deep percolation probably moves distances substantially greater than $3.6 \mathrm{~km}$ and requires traveltimes greater than 90 years. 


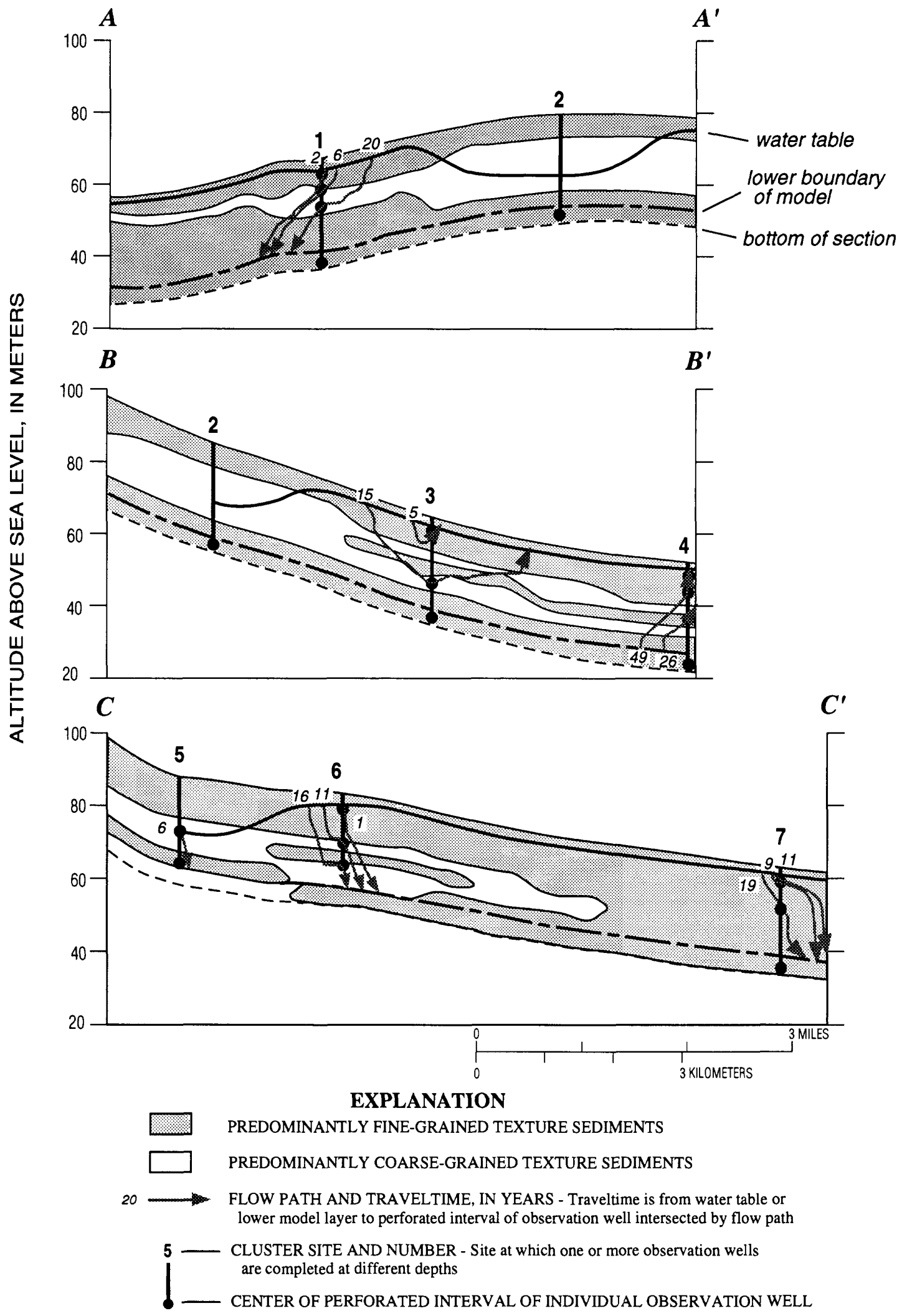

Figure 9. Simulated ground-water flow paths and advective traveltimes from the water table to sampling points at cluster sites projected onto geohydrologic sections $A-A^{\prime}, B-B^{\prime}$, and $C-C^{\prime}$. Locations of sections shown in figure 2. 


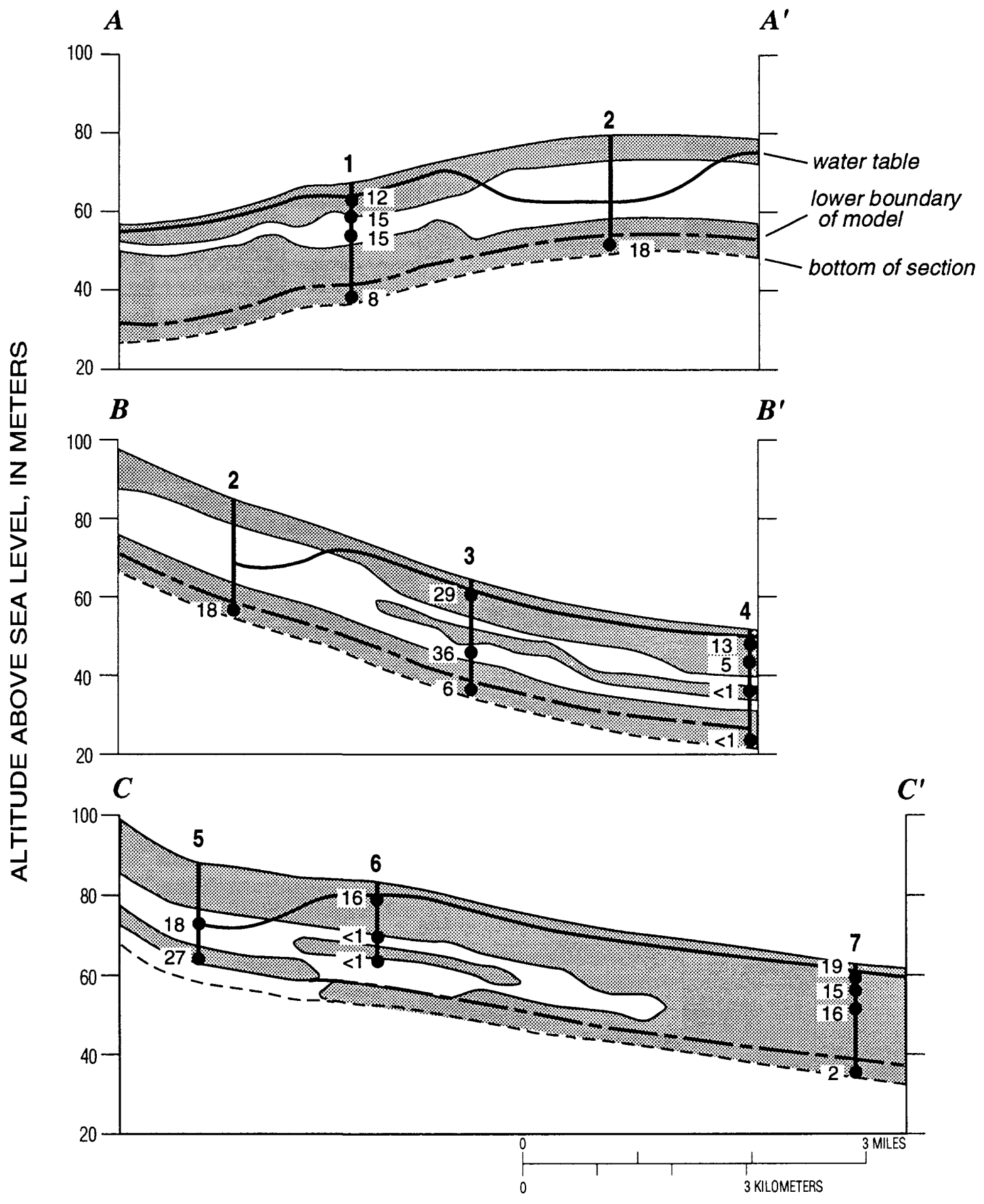

EXPLANATION

PREDOMINANTLY FINE-GRAINED TEXTURE SEDIMENTS

PREDOMINANTLY COARSE-GRAINED TEXTURE SEDIMENTS

CLUSTER SITE AND NUMBER - Site at which one or more obervation wells
are completed at different depths
CENTER OF PERFORATED INTERVAL OF INDIVIDUAL OBSERVATION WELL -
Number is tritium concentration, in tritium units. <, actual value is less than value shown

Figure 10. Tritium in water from observation wells at cluster sites projected onto geohydrologic sections $A-A^{\prime}, B-B^{\prime}$, and $C-C^{\prime}$. Locations of sections shown in figure 2. 


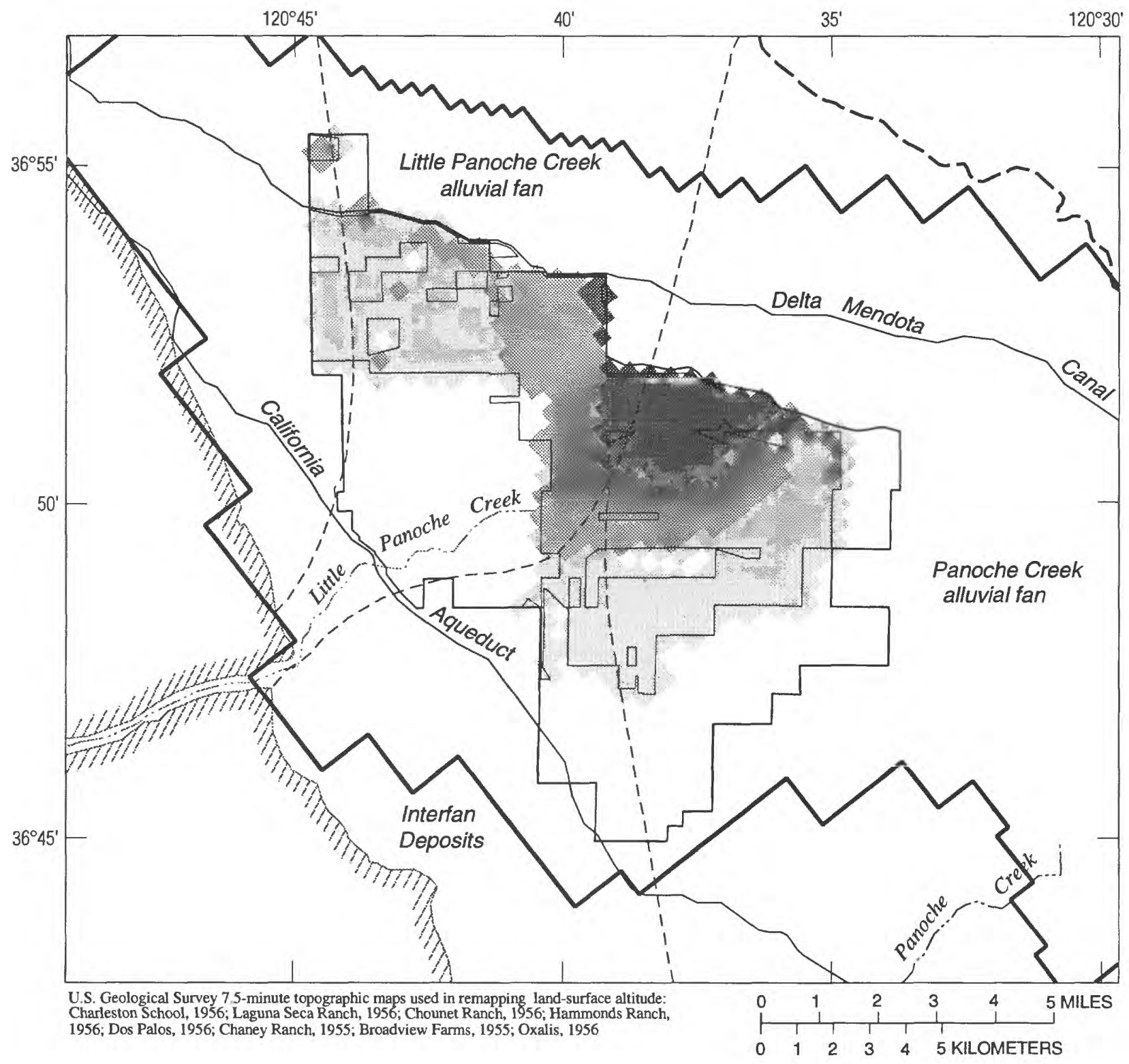

EX P L A N A T I O N

CONTRIBUTING SOURCES TO DRAINFLOW

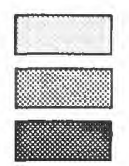

Recharge to the saturated zone

Recharge and lateral flowing ground water

Recharge and upward-moving deep percolation
BOUNDARIES

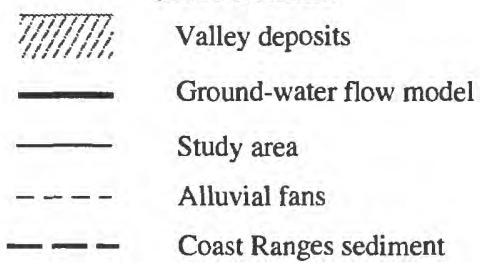

Figure 11. Delineation of drained areas that intercept mostly recharge to the saturated zone, lateral ground-water flow, and upward-moving deep percolation in part of the western San Joaquin Valley. 


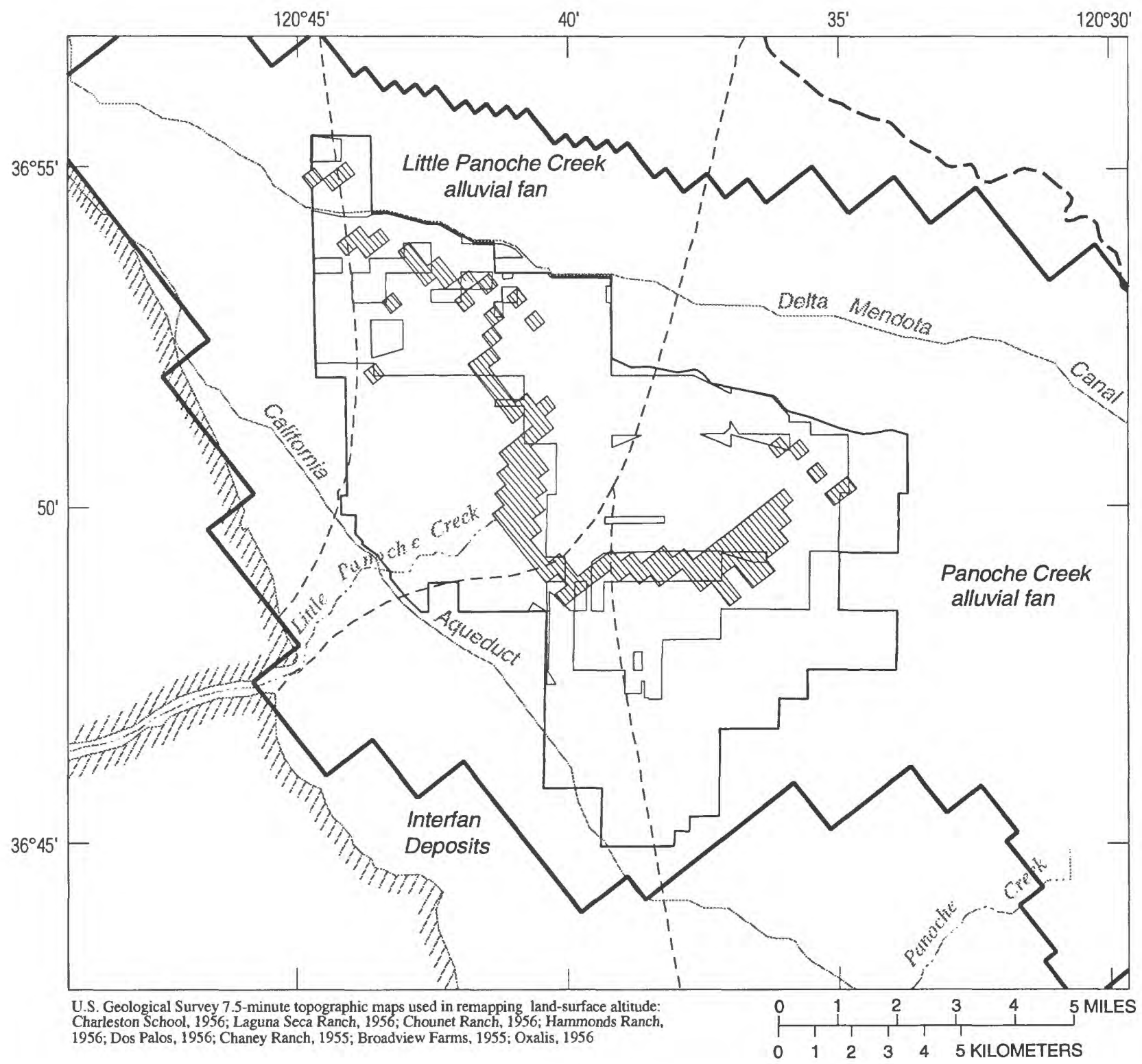

\section{E X P L A N A T I O N}

RECHARGE AREAS FOR LATERAL GROUND-WATER FLOW INTERCEPTED BY DOWNSLOPE DRAINAGE SYSTEMS

BOUNDARIES

T/1/1/1/, $\quad$ Valley deposits

$-\quad$ Ground-water flow model
$-\quad$ Study area

Alluvial fans

- Coast Ranges sediment

Figure 12. Recharge areas contributing to lateral ground-water flow and downslope drainflow in part of the western San Joaquin Valley. 
The distribution of discharge and recharge areas relative to regional ground-water flow and drainflows is confirmed by the distribution of drainage-system age in the study area (fig. 13). Many drainage systems in the northern part of the study area were installed prior to 1966, and most drainage systems downslope of the recharge areas were installed prior to 1975 , indicating that the water table has stabilized in the recharge areas. In contrast, most drainage systems in the southern part of the study area were installed after 1975 . The drainage system $3 \mathrm{~km}$ northeast of site 5 was installed as recently as 1985 , indicating that the depth to the water table in the southernmost part of the study area probably is decreasing.

The delineation of contributing sources to drainflow is important for defining drainflow quality because the depth distribution of ground-water flow paths to the drain laterals and concentration of chemical constituents in the aquifer affect drainflow quality (Fio and Deverel, 1991). For example, upwardmoving deep percolation at site 4 contributes ground water to total drainflow that is relatively high in salinity and selenium concentrations. The upward movement of salts and selenium will affect drainflow quality over the short term because of hydrologic changes during the annual irrigation cycle and over the long term because of alterations in water-use practices. Hence, chemical data and model-simulation results can be used to help explain temporal and spatial variability in salt and selenium concentrations in drainflows.

\section{EFFECTS OF GROUND WATER ON QUALITY OF DRAINFLOW}

Drainflow salinity (as measured by the concentration of dissolved solids in drainwater) generally is constant over time at sites 1 and 3 but is inversely related to flow at site 4 (fig. 14). Dissolved-solids concentrations were highest at site 4 during nonirrigated periods when flow was at a relative minimum. In contrast, dissolved-solids concentrations were substantially less during irrigated periods when flow was at a relative maximum. The dissolvedsolids concentrations in total drainflow discharged from the study area decreased during irrigated periods and increased during nonirrigated periods, indicating a similar inverse relation between flow and quality for other fields in the study area (not shown in fig. 14).
Temporal variability in dissolved-solids concentrations in drainflow at site 4 is explained by the depth distribution of soluble constituents in the ground-water flow system. The total ionic composition of ground-water samples is variable with depth at site 4 (fig. 6), and the highest concentration of dissolved constituents is about $8.3 \mathrm{~m}$ below land surface. Dissolved-solids concentrations are highest during nonirrigated conditions because of an increase in the proportional contribution of upward-moving deep percolation to total drainflow at this site; during irrigated conditions, most of the drainflow at site 4 is from irrigation recharge and shallow ground water with lower dissolved-solids concentrations. In contrast, the total ionic composition of ground-water samples at sites 1 and 3 is fairly uniform with depth (fig. 6). The depth distribution of flow paths to the drainage systems at these sites also changes during irrigated and nonirrigated conditions, but the concentration of dissolved solids in drainflow does not vary substantially.

The coefficient of variation, calculated in this study as the ratio of the standard deviation in dissolved-solids concentrations and the annual average of these concentrations (expressed as a percent), was used to assess the temporal and spatial variability in ground-water and drainflow salinity. The distribution of coefficient of variation values indicates that dissolved-solids concentrations in drainflow from fields at the margins of the alluvial fans vary by 10 percent or greater of the annual average (fig. 15). These drainage systems are in areas of historical ground-water discharge and high soil salinity (Deverel and Gallanthine, 1989) and probably collect relatively deep ground water during nonirrigated periods, which is high in dissolved-solids concentrations. Upward regional hydraulic head gradients in these areas probably have impeded the downward displacement of soluble constituents in the ground-water flow system, resulting in a distribution of dissolved-solids concentrations that is variable with depth. During irrigated periods, these drainage systems collect substantial quantities of irrigation recharge and shallow ground water that is relatively low in dissolved-solids concentrations and thus the proportional contribution of the deep ground water to drainflows is reduced. In contrast, the downward and lateral movement of ground water in the upslope areas has probably displaced soluble constituents beyond the effect of the drainage systems, and the resulting drainflow salinity is constant over time because the distribution of dissolved-solids concentrations in ground water is fairly uniform with depth. 


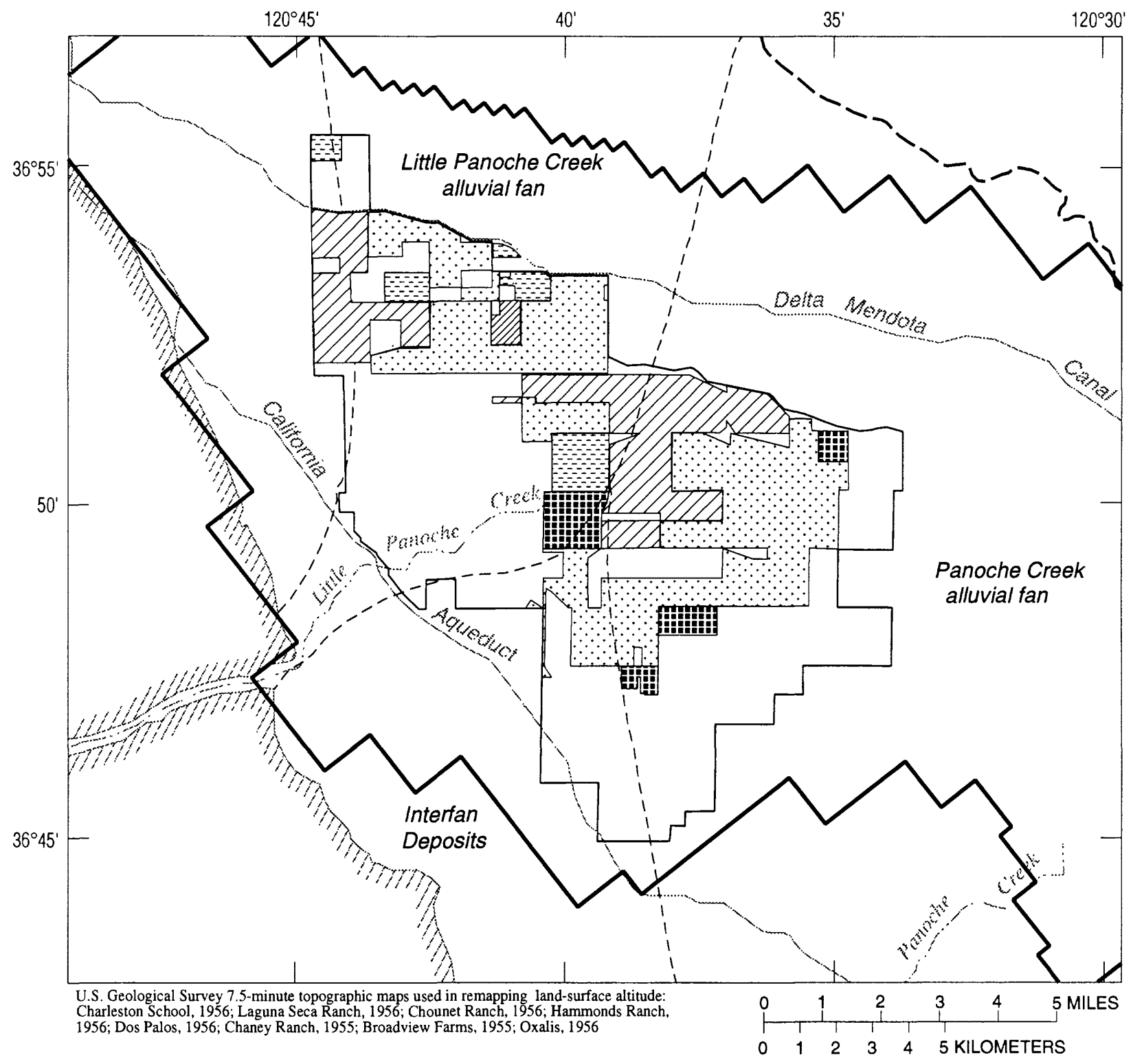

E X P LA NATI O N

INSTALLATION DATES

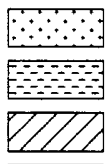

曲曲
Unknown

Prior to 1966

Between 1966 and 1975

After 1975
BOUNDARIES

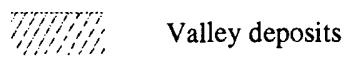

Ground-water flow model

$---\quad$ Alluvial fans

- - Coast Ranges sediment

Figure 13. Installation dates of selected drainage systems in part of the western San Joaquin Valley (blank areas in study area are undrained; installation dates for areas outside the study area boundaries are not shown). 


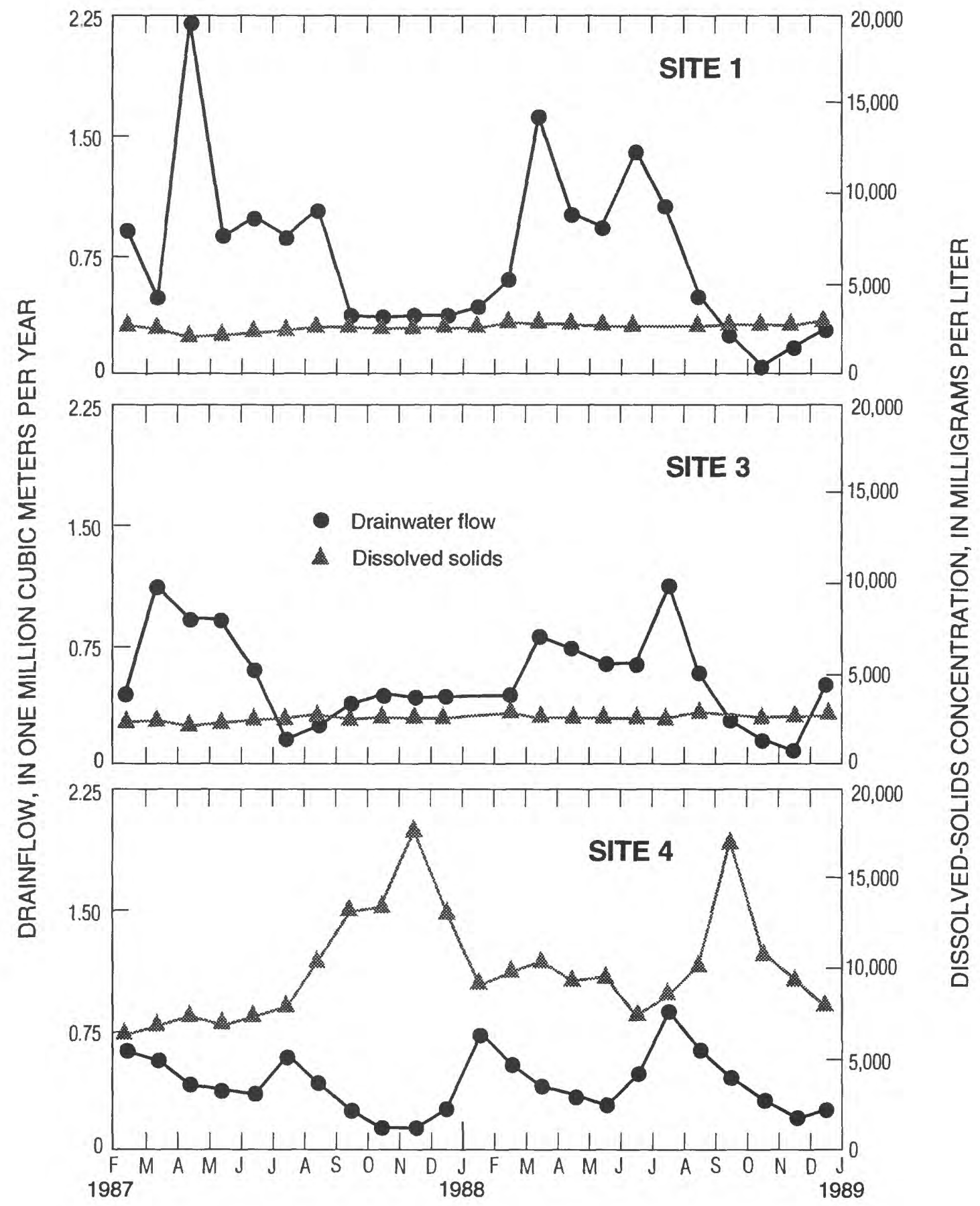

Figure 14. Drainwater flow and dissolved solids for drainage systems at sites 1, 3, and 4 from part of the western San Joaquin Valley.

The spatial distribution of median selenium concentrations in drainflows shows general correlation with the drainage systems having coefficient of variation values greater than 10 percent (fig. 16). High selenium concentrations in drainflow can be explained by differences in geologic source materials, drainage-system age, and regional ground-water flow. For example, the drainage basin of Panoche Creek contains rock formations considered significant sources of selenium in soil and ground water in the area (Presser and others, 1990). These source areas explain why selenium concentrations in drainflows 


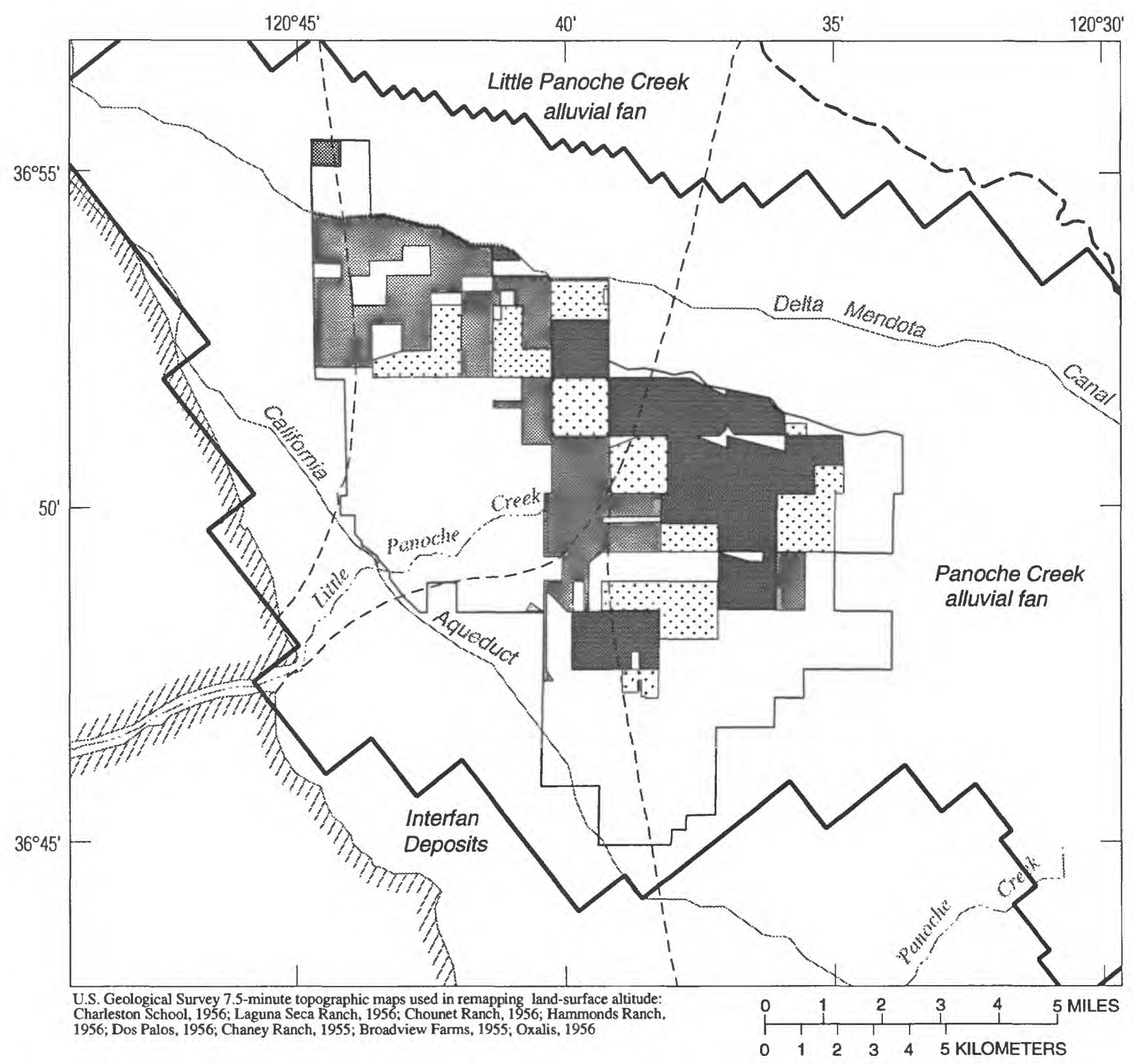

E X P L A N A T I O N

\begin{tabular}{|c|c|c|c|}
\hline & \multirow{2}{*}{$\begin{array}{l}\text { BOUNDARIES } \\
\text { Valley deposits }\end{array}$} \\
\hline$\because \because$ & No data & "ד:1/1/1i, & \\
\hline & $\begin{array}{l}\text { Seasonal variation in dissolved-solids } \\
\text { concentrations in drainwater less than } \\
10 \text { percent }\end{array}$ & & $\begin{array}{l}\text { Ground-water flow model } \\
\text { Study area }\end{array}$ \\
\hline & $\begin{array}{l}\text { Seasonal variation in dissolved-solids } \\
\text { concentrations in drainwater greater than } \\
\text { or equal to } 10 \text { percent }\end{array}$ & --- & $\begin{array}{l}\text { Alluvial fans } \\
\text { Coast Ranges sediment }\end{array}$ \\
\hline
\end{tabular}

Figure 15. Areal distribution of the seasonal variation in dissolved-solid concentrations in drainwater in part of the western San Joaquin Valley (blank areas in study area are undrained; drained areas outside the study area boundaries are not shown). 


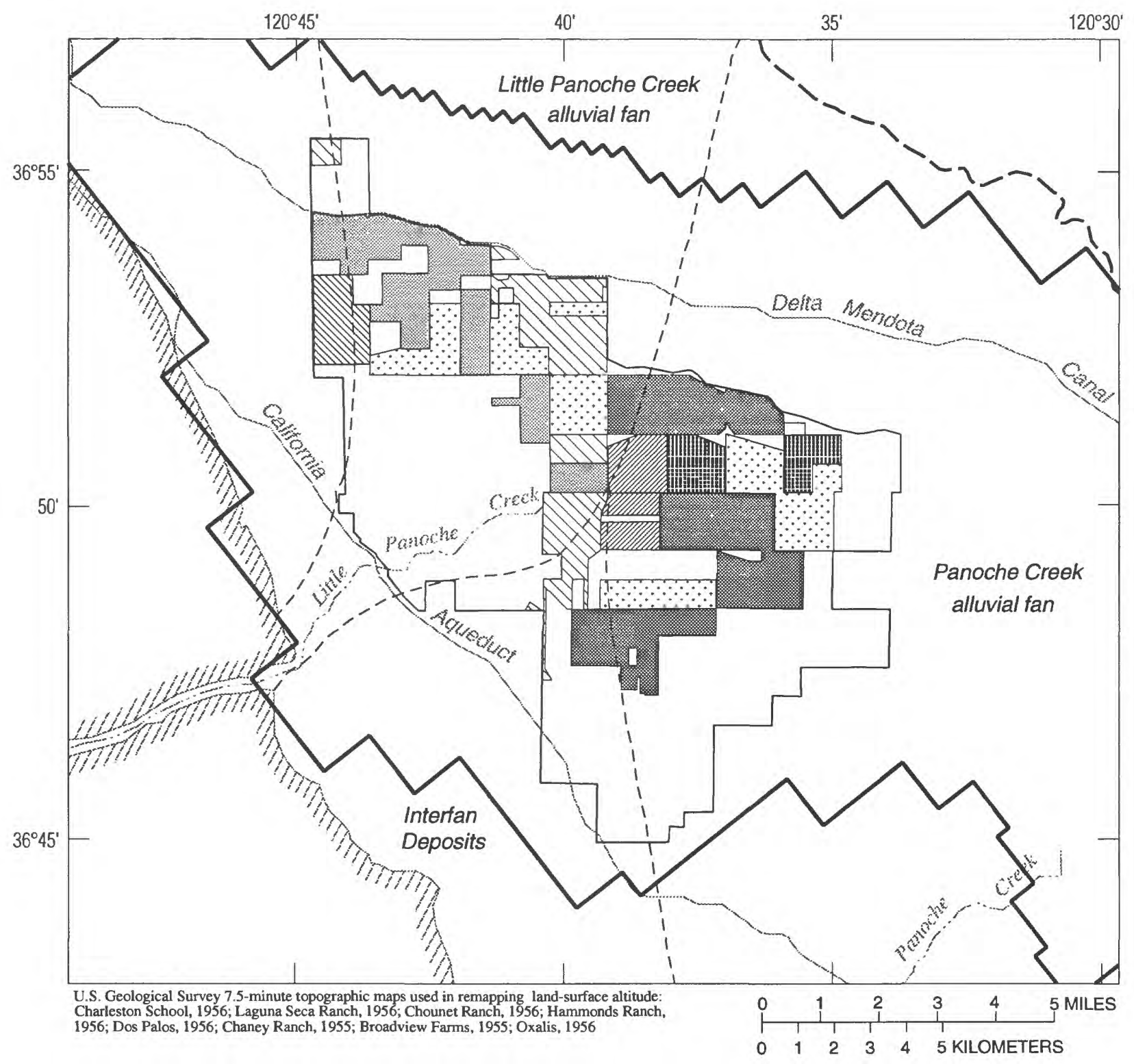

E X P L A N A T I O N

SELENIUM CONCENTRATIONS, IN MILLIGRAMS PER LITER

$\begin{array}{ll}\therefore \because \because \because \text { No data } & \text { Greater than or equal to } 100 \text { and less than } 500 \\ \text { Less than } 20 & \text { Greater than or equal to } 500 \text { and less than } 1,000 \\ \text { Greater than or equal to } 20 \text { and less than } 100 & \text { Greater than or equal to } 1,000\end{array}$

BOUNDARIES

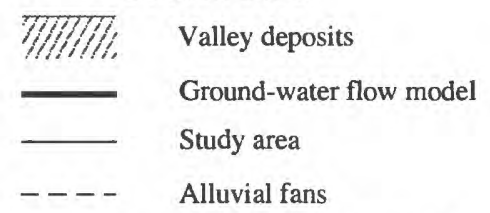

- $-\quad$ Coast Ranges sediment

Figure 16. Areal distribution of selenium concentrations in drainwater in part of the western San Joaquin Valley (blank areas in study area are undrained; drained areas outside the study area boundaries are not shown). 

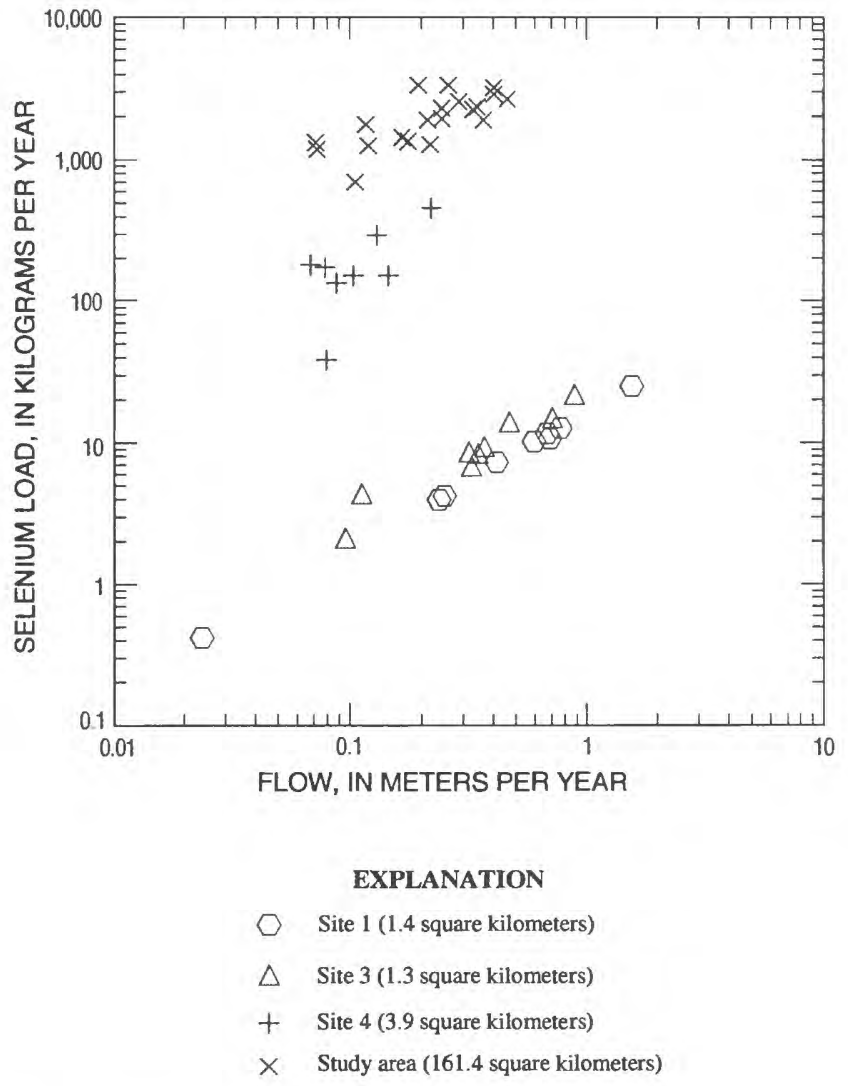

Figure 17. Relation between measured selenium loads and drainwater flow for drainage systems at sites 1, 3, and 4 and total drainage in part of the western San Joaquin Valley.

generally are higher from drainage systems beneath fields on the Panoche Creek fan than beneath fields on the Little Panoche Creek fan. Furthermore, the drainage systems on the Little Panoche Creek fan generally are older than systems on the Panoche Creek fan, allowing greater time periods for irrigation recharge to displace selenium concentrations to the drainage systems and to deeper depths in the aquifer.

The quantity of selenium (mass) in drainflows was assessed by calculating loads. The general loadflow relation for the drainage systems near sites 1,3 , and 4 and for the total drainflow from the study area is plotted in figure 17. Loads generally are proportional to flow, and linear relation between load and drainflow indicates that reductions in the quantity of drainflow should result in a proportional reduction in load. For example, reductions in irrigation recharge and increased pumping will reduce the quantity of drainflow (Fio, 1994). The effects of reduced recharge and increased pumping on the distribution of salinity and selenium in the ground-water flow system, however, is uncertain. For example, a reduction in irrigation recharge probably will increase the proportional contribution of deep ground water to drainflows (Fio, 1994), resulting in increased selenium concentrations but a net reduction in load. The smaller head gradients and ground-water velocities will increase the time necessary to displace the poor quality ground water into the drain laterals and further downward in the aquifer. Increased pumping will decrease the contribution of upward-moving deep percolation to drainflow (Fio, 1994), probably resulting in a decrease in selenium concentrations and loads. However, the increased downward gradients and velocities may increase the downward displacement of poor quality ground water and result in substantial quantities of contaminated water intercepted by the pumping wells. Further study, therefore, is necessary to quantify the long-term effects of recharge and pumping conditions for ground-water and drainflow quality.

\section{SUMMARY AND CONCLUSIONS}

Salt and selenium concentrations in drainwater are affected by the distribution of ground-water flow paths to the drainage systems and the spatial distribution of chemical constituents in the ground-water system in the western San Joaquin Valley, California. Results of water-quality sampling and analysis and ground-water flow simulation show that hydrologic and chemical processes can affect the spatial and temporal distribution of drainflow quality. These processes have local effects, as is evident from seasonal variability in on-farm drainflow, and regional effects related to the interception of lateral-flowing ground water and upward-moving deep percolation.

Salt and selenium concentrations in ground water vary areally and with depth in the western San Joaquin Valley. The soils and aquifer materials in the study area consist of sediments deposited as alluvial fans formed by Little Panoche and Panoche Creeks. The source materials within the respective drainage basins impart important chemical differences in ground water beneath the two fans. For example, ground water sampled from beneath the Little Panoche Creek fan is a sodium chloride type, relatively low in total ionic content, with selenium concentrations that range from less than 1 to 27 micrograms per liter; ground water sampled from beneath the Panoche Creek fan is a sodium sulfate type, relatively high in total ionic content, with selenium concentrations that range from 20 to 400 micrograms per liter. Stable isotopes in some ground-water 
samples from these areas indicate partial evaporation from the shallow water table, which enriched the ground water in salts and selenium.

The drainage systems intercept a combination of irrigation recharge and deeper ground water; deeper ground water in low-lying areas and at the margins of the fans can have higher concentrations of salinity and selenium. For example, at one site the highest concentration of selenium (1,700 micrograms per liter) was detected 8.3 meters below land surface. Isotopic data indicate that this water has been enriched by partial evaporation and thus was at or near land surface in the past. The displacement of this water is the result of irrigation, drainage, and upward-moving deep percolation of water originating as upslope recharge.

The proportional contribution of shallow and deep flow intercepted by the drainage system is affected by varying hydrologic conditions. During nonirrigated periods, the contribution of deep flow increases, resulting in an increase in the concentration of salinity and selenium in drainflow. Conversely, during irrigated periods, the contribution of irrigation recharge and shallow ground water increases, resulting in a decrease in the concentration of salinity and selenium in drainflow. Selenium load is proportional to drainflows, indicating that reducing drainflow should reduce selenium loads. Alterations in ground-water flow paths and velocities, however, will have uncertain effects for the redistribution of chemical constituents in the ground-water system and potential changes in the distribution of ground-water and drainflow quality.

\section{References Cited}

Belitz, Kenneth, and Heimes, F.J., 1990, Character and evolution of the ground-water flow system in the central part of the western San Joaquin Valley, California: U.S. Geological Survey Water-Supply Paper 2348, $28 \mathrm{p}$.

Belitz, Kenneth, Phillips, S.P., and Gronberg, J.M., 1992, Numerical simulation of ground-water flow in the central part of the western San Joaquin Valley, California: U.S. Geological Survey Open-File Report 91-535, $71 \mathrm{p}$.

Bodine, M.W., Jr., and Jones, B.F., 1986, The salt norm: A quantitative chemical-mineralogical characterization of natural waters: U.S. Geological Survey WaterResources Investigations Report 86-4086, 130 p.
Craig, H., 1961, Isotopic variations in meteoric water: Science, v. 133, p. 1702-1703.

Cutter, G.A., 1978, Species determination of selenium in natural waters: Analytica Chimica Acta, v. 98, p. 59-66.

Davis, G.H., 1961, Geologic control of mineral composition of stream waters of the eastern slope of the southern Coast Ranges, California: U.S. Geological Survey Water-Supply Paper 1535-B, 30 p.

Davis, G.H., and Coplen, T.B., 1989, Late Cenozoic paleometeorology and structural history of the central Coast Ranges deduced by chemical and isotopic hydrology of ground water of the central west side of the San Joaquin Valley, California: Geological Society of America Special Publication 234, 40 p.

Deverel, S.J., and Fio, J.L., 1991, Ground-water flow and solute movement to drain laterals, western San Joaquin Valley, California. 1. Geochemical assessment: Water Resources Research, v. 27, no. 9, p. 2233-2246.

Deverel, S.J., and Fujii, Roger, 1988, Processes affecting the distribution of selenium in shallow ground water of agricultural areas, western San Joaquin Valley, California: Water Resources Research, v. 24, no. 4, p. 516-524.

Deverel, S.J., and Gallanthine, S.K., 1989, Relation of salinity and selenium in shallow ground water to hydrologic and geochemical processes, western San Joaquin Valley, California: Journal of Hydrology, v. 109 , p. $125-149$.

Deverel, S.J., Gilliom, R.J., Fujii, Roger, Izbicki, J.A., and Fields, J.C., 1984, Areal distribution of selenium and other inorganic constituents in shallow ground water of the San Luis Drain service area: U.S. Geological Survey Water-Resources Investigations Report 84-4319, $67 \mathrm{p}$.

Dibblee, T.W., 1975, Geologic map of the Pacheco Pass, Hollister, Quien Sabe, Ortigalita Peak, San Benito, Panoche Valley and Tumey Hills quadrangles, San Benito, Santa Clara, Merced and Fresno Counties, California: U.S. Geological Survey Open-File Report 75-0394.

Epstein, S., and Mayeda, T., 1953, Variation of the O-18 content of waters from natural sources: Geochimica et Cosmochimica Acta, 4, p. 213-224.

Fio, J.L., 1994, Calculation of a water budget and delineation of contributing sources to drainflows in the western San Joaquin Valley, California: U.S. Geological Survey Open-File Report 94-45, 39 p.

Fio, J.L., and Deverel, S.J., 1991, Ground-water flow and solute movement to drain laterals, western San Joaquin Valley, California. 2. Quantitative hydrologic assessment: Water Resources Research, v. 27, no. 9, p. 2247-2257. 
Fishman, M.J., and Friedman, L.C., eds., 1989, Methods for determination of inorganic substances in water and fluvial sediments: U.S. Geological Survey Techniques of Water-Resources Investigations, book 5, chap. A1, $545 \mathrm{p}$.

Harbaugh, A.W., 1990, A computer program for calculating subregional water budgets using results from the U.S. Geological Survey modular three-dimensional finite-difference ground-water flow model: U.S. Geological Survey Open-File Report 90-392, 46 p.

International Atomic Energy Agency, 1976, Procedures and techniques critique of tritium enrichment by electrolysis: Technical Note No. 19.

Kendall, Carol, and Coplen, T.B., 1985, Multisample conversion of water to hydrogen by zinc for stable isotope determination: Analytical Chemistry, v. 57, p. 1437-1440.

McDonald, M.G., and Harbaugh, A.W., 1988, A modular three-dimensional finite-difference ground-water flow model: U.S. Geological Survey Techniques of WaterResources Investigations, book 6, chap. A1, 586 p.

Mendenhall, W.C., Dole, R.B., and Stabler, Herman, 1916, Ground water in the San Joaquin Valley, California: U.S. Geological Survey Water-Supply Paper 398, $310 \mathrm{p}$.

Michel, R.L., 1989, Tritium deposition in the continental United States, 1953-1983: U.S. Geological Survey Water-Resources Investigations Report 89-4072, 46 p.

Ohlendorf, H.M., Hothem, R.L., Bunck, C.M., Aldrich, T.W., and Moore, J.F., 1986, Relationships between selenium concentrations and avian reproduction: North American Wildlife and Natural Resources Conference, 51st, Reno, Nevada, Transactions, 1986, p. 330-442.

Pollock, D.W., 1988, Semianalytical computation of path lines for finite-difference models: Ground Water, v. 26, p. $743-750$.

Pollock, D.W., 1989, Documentation of computer programs to compute and display pathlines using results from the U.S. Geological Survey modular three-dimensional finite difference ground-water flow model: U.S. Geological Survey Open-File Report 89-381, 188 p.

Presser, T.S., and Barnes, Ivan, 1984, Selenium concentrations in waters tributary to and in the vicinity of the Kesterson National Wildlife Refuge, Fresno and Merced Counties, California: U.S. Geological Survey Water-Resources Investigations Report 84-4112, 26 p.

Presser, T.S., Swain, W.C., Tidball, R.R., and Severson, R.C., 1990, Geologic sources, mobilization, and transport of selenium from the California Coast Ranges to the western San Joaquin Valley: A reconnaissance study: U.S. Geological Survey Water-Resources Investigations Report 90-4070, $66 \mathrm{p}$.

Stiff, H.A., Jr., 1951, The interpretation of chemical water analysis by means of patterns: Journal of Petroleum Technology, v. 3, no. 10, p. 15-17.

Wood, W.W., 1981, Guidelines for collection and field analysis of ground-water samples for selected unstable constituents: U.S. Geological Survey Techniques of Water-Resources Investigations, book 1, chap. D2, $24 \mathrm{p}$. 